\title{
Biomarkers and $C$ and $S$ Isotopes of the Permian to Triassic Solid Bitumen and Its Potential Source Rocks in NE Sichuan Basin
}

\author{
Chunfang Cai, ${ }^{1,2,3}$ Chenlu Xu, ${ }^{2}$ Wenxiang He, ${ }^{1}$ Chunming Zhang, ${ }^{1}$ and Hongxia $\mathrm{Li}^{2}$ \\ ${ }^{1}$ Key Laboratory of Exploration Technologies for Oil and Gas Resources of Ministry of Education, Yangtze University, \\ Wuhan, Hubei 430100, China \\ ${ }^{2}$ Key Laboratory of Petroleum Resources Research, Institute of Geology and Geophysics, Chinese Academy of Sciences, \\ Beijing 100029, China \\ ${ }^{3}$ College of Earth Sciences, University of Chinese Academy of Sciences, Beijing 100049, China
}

Correspondence should be addressed to Chunfang Cai; cai_cf@mail.iggcas.ac.cn

Received 16 February 2017; Revised 22 April 2017; Accepted 11 June 2017; Published 13 August 2017

Academic Editor: Timothy S. Collett

Copyright (C) 2017 Chunfang Cai et al. This is an open access article distributed under the Creative Commons Attribution License, which permits unrestricted use, distribution, and reproduction in any medium, provided the original work is properly cited.

\begin{abstract}
The potential parent source rocks except from Upper Permian Dalong Formation $\left(\mathrm{P}_{3} \mathrm{~d}\right)$ for Upper Permian and Lower Triassic solid bitumen show high maturity to overmaturity with equivalent vitrinite reflectance ( $\mathrm{ER}_{o}$ ) from $1.7 \%$ to $3.1 \%$ but have extractable organic matter likely not contaminated by younger source rocks. $\mathrm{P}_{3} \mathrm{~d}$ source rocks were deposited under euxinic environments as indicated by the pyrite $\delta^{34} S$ values as light as $-34.5 \%$ and distribution of aryl isoprenoids, which were also detected from the Lower Silurian $\left(\mathrm{S}_{1} \mathrm{l}\right)$ source rock and the solid bitumen in the gas fields in the west not in the east. All the solid bitumen not altered by thermochemical sulfate reduction (TSR) has $\delta^{13} \mathrm{C}$ and $\delta^{34} \mathrm{~S}$ values similar to part of the $\mathrm{P}_{3} 1$ kerogens and within the $\mathrm{S}_{1} 1$ kerogens. Thus, the eastern solid bitumen may have been derived from the $\mathrm{P}_{3} 1$ kerogens, and the western solid bitumen was likely to have precracking oils from $\mathrm{P}_{3} 1$ kerogens mixed with the $\mathrm{S}_{1} 1$ or $\mathrm{P}_{3} \mathrm{~d}$ kerogens. This case-study tentatively shows that $\delta^{13} \mathrm{C}$ and $\delta^{34} \mathrm{~S}$ values along with biomarkers have the potential to be used for the purpose of solid bitumen and source rock correlation in a rapidly buried basin, although further work should be done to confirm it.
\end{abstract}

\section{Introduction}

Natural gases from the Upper Permian Changxing $\left(\mathrm{P}_{3} \mathrm{ch}\right)$ to Lower Triassic Feixianguan Formation $\left(\mathrm{T}_{1} \mathrm{f}\right)$ from northern Sichuan Basin are associated with abundant solid bitumen and are thus considered to have been derived from oil cracking in the reservoirs. The solid bitumen and associated gases may have mainly derived from Upper Permian Longtan Formation based on correlation of biomarkers and $\delta^{13} \mathrm{C}$ values of the source rocks and solid bitumen (pyrobitumen) in reservoirs [1-4]. However, the conclusion may not be effective, based on the consideration of the following two aspects.

Thermochemical sulfate reduction (TSR), redox reactions between petroleum and sulfates in deeply buried reservoirs, is concluded to occur in this area [5-7] and results in alteration in the solid bitumen [8]. TSR is found to result in negative shift in $\delta^{13} \mathrm{C}$ values [9] (Machel et al., 1995) and positive shift in $\delta^{34} \mathrm{~S}$ due to incorporation of ${ }^{12} \mathrm{C}$-rich alkanes and ${ }^{34} \mathrm{~S}$ rich TSR sulfides [8, 10-14] (Cai et al., 2001); thus, $\delta^{13} \mathrm{C}$ and $\delta^{34} \mathrm{~S}$ values can be used as effective tools for oil-source rock correlation only where there has been little or no TSR and oil generation occurred at a closed or semiclosed system in which the source rock was rapidly buried during the period [13-16]. In such a burial environment with oil cracking to solid bitumen and the associated gas, the solid bitumen and its parent kerogen are expected to have similar $\delta^{13} \mathrm{C}$ and $\delta^{34} \mathrm{~S}$ values; thus it is possible to use $\delta^{13} \mathrm{C}$ and $\delta^{34} \mathrm{~S}$ values for the purpose of the correlation between source rock and solid bitumen and consequently to determine the source rock for the gases. 
On the other hand, natural gases in eastern gas fields show significant differences in chemical composition and $\delta^{13} \mathrm{C}$ values from those in western gas fields (Cai et al., 2011) [18-20]. The geochemical features are found to have been controlled by kerogen type and/or maturity [21, 22], and thus, the two-side gases were proposed, although not proven, to have been derived from different source rocks (Cai et al., 2011). If so, significant differences in geochemical features in the associated solid bitumen are expected.

In this study, solid bitumen from the Upper Permian and Lower Triassic and source rocks from the Lower Cambrian, Lower Silurian, and Upper Permian were analyzed for molecular composition and $\delta^{13} \mathrm{C}$ and $\delta^{34} \mathrm{~S}$ values. The specific objectives of this study are to determine (1) if any differences exist in molecular composition between western and eastern solid bitumen; (2) what the differences among potential source rocks of different ages are; and (3) from which source rock the solid bitumen and the associated gases were likely derived.

\section{Geological Setting}

Commercial natural gas is being produced from the Lower Permian Changxing Formation and Upper Triassic Feixianguan Formation in MB, PG, LJ, and Po gas fields in the east and $\mathrm{HB}, \mathrm{YB}$, and LG gas fields in the west, of the northern Sichuan Basin, southwestern China (Figure 1(a)). The geological setting has been published in Cai et al. [5], Cai et al. (2014), Ma et al. [23], and Jin et al. [3]. It is a late Mesozoic-Cenozoic foreland basin overlying an Ediacaran-Middle Mesozoic passive margin. The basement framework of the basin was established during the Chengjiang tectonic movement (about $750 \mathrm{Ma}$ ) with western and eastern lows of ductile basement separated by a central uplift of brittle lithologies. A major marine transgression occurred during early Ediacaran with the deposition of Doushantuo Formation mudstone and shale and Dengying Formation dolostone and cherty dolostone. A second major marine transgression resulted in the deposition of opento restricted-marine facies shale, siltstone, limestone, and dolostone during the Cambrian. A third marine transgression during the Early Ordovician to the Early Silurian resulted in the widespread deposition of black shales in an open marine environment. Marine sedimentation was interrupted during the late Silurian Caledonian Orogeny when the Sichuan Basin was uplifted and exposed, resulting in minimal Devonian deposition. Middle Carboniferous sedimentation was limited to the eastern part of the Sichuan Basin. Following the Caledonian Orogeny, marine transgression occurred during the earliest Permian. The Lower Permian is composed of platform carbonates with a typical thickness of 300-500 m. Submarine basalt eruption occurred at the end of the Lower Permian. The Upper Permian Longtan Formation is composed of platform carbonates with alternating marine and terrestrial coal bearing mudstone and marlstone (Figure 1(c)). During the Changxing period of the latest Permian, a rapid basement subsidence took place mainly in the Kaijiang and Liangping areas (Wei et al., 2004), resulting in the Kaijiang-Liangping Trough separating a semi-isolated evaporated carbonate platform to the east from a large, shallow, carbonate platform to the west during the period from the Changxing to the Feixianguan (Early Triassic) (Figure 1(b)). Lower Triassic Feixianguan Fm is considered to deposit in a range of environments from basinal through a narrow slope to open platform and evaporated platform environments. The Upper Permian Changxing Formation reefal dolostone and the Lower Triassic Feixianguan Formation shelf and platform-margin shoal oolitic dolostone are the main reservoirs. As a result of the Yinzi Orogeny between the Middle and Upper Triassic, the Sichuan Basin was uplifted and exposed. Upper Triassic to Cretaceous sediments are composed of freshwater lacustrine-alluvial clastics with local coal beds with thickness of 2000-5000 m.

The potential source rocks of paleo-oils for the gases and the associated solid bitumen include Lower Cambrian black shale $\left(\mathrm{Cam}_{1}\right)$, Lower Silurian Longmaxi Fm $\left(\mathrm{S}_{1} \mathrm{l}\right)$ mudstone and shale, Upper Permian Longtan Fm $\left(\mathrm{P}_{3} \mathrm{l}\right)$ or isochronous Wujiaping $\mathrm{Fm}\left(\mathrm{P}_{3} \mathrm{w}\right)$ mudstone, shale, and marlstone, and Upper Permian Dalong Fm $\left(\mathrm{P}_{3} \mathrm{~d}\right)$ or isochronous Changxing Fm $\left(\mathrm{P}_{3} \mathrm{ch}\right)$ shale and mudstone [24-26]. Organic matter in these source rocks is primarily type $\mathrm{I}$ sapropelic and $\mathrm{II}_{1}$ humic-sapropelic kerogens and exhibits similar biomarker composition but different $\delta^{13} \mathrm{C}$ values [1-3].

Upper Permian Dalong Fm or Changxing Fm source rocks are dark gray, gray black carbonaceous shale, calcareous mudstone, siliceous mudstone, and silicates with a thickness up to $30 \mathrm{~m}$ and TOC up to $13.5 \%$ [17]. These source rocks have a limited distribution and occur along the Guangyuan-Wangcang Trough, the Kaijiang-Liangping Trough, and the Chengkou-Exi Trough. The source rocks have bitumen reflectance $\left(R_{b}\right)$ of $4.4 \%$ or $R_{o}$ equivalent $\left(\mathrm{ER}_{o}\right)$ of $3.1 \%$ in well $\mathrm{HB1}\left(\mathrm{ER}_{o}=0.618 R_{b}+0.40\right)$ [17] and $R_{b}$ from $1.4 \%$ to $2.2 \%$ (or $\mathrm{ER}_{o}$ of 1.3 to $1.8 \%$ ) in the Wanyuan area. Organic matter in the Changjianggou section at Guangyuan shows much lower maturity with $R_{b}$ of $0.69 \%$ or $\mathrm{ER}_{o}$ of $0.8 \%$ $[17,27]$.

Upper Permian Longtan $\left(\mathrm{P}_{3} \mathrm{l}\right)$ Fm source rocks include gas-prone marine-terrigenous transitional facies black shale, mudstone, and laminar coal seams in the middle and southern part of NE Sichuan Basin $[8,23,28,29]$ and deep water shelf facies oil-prone source rocks in the BazhongDazhou depression in the northern Sichuan Basin such as in wells HB1, MB3, and PG5 $[4,29]$. The source rocks in the Bazhong-Dazhou area were measured to have TOC from 0.6 to $10.8 \%$ with an average of $2.06 \%(n=53)$ and thickness from $40 \mathrm{~m}$ to $140 \mathrm{~m}$ with the maximum of $160 \mathrm{~m}$ in $\mathrm{MB}, \mathrm{PG}$, and DU gas fields [27]. $R_{b}$ for the marlstone was measured to have an average of $4.3 \%(n=5)$ or $\mathrm{ER}_{o}$ of $3.1 \%$ [27].

Lower Silurian Longmaxi Fm $\left(\mathrm{S}_{1} \mathrm{l}\right)$ mudstone and shale have total organic carbon values (TOC) up to $6.5 \%$ and are approximately $105 \mathrm{~m}$ thick with TOC $>1.0 \%$ in the Shizhu area in the southeast of the gas fields [30]. It is $55 \mathrm{~m}$ thick in the Wuxi area east of the gas fields [24]. The source rocks have $R_{b}$ values from $4.2 \%$ to $4.9 \%$ or $\mathrm{ER}_{o}$ from $3.0 \%$ to $3.4 \%$ at Shizhu. Source rocks with higher TOC were deposited in anoxic deep water shelf during the deposition of lower Longmaxi Fm Subsequently, the environment becomes 


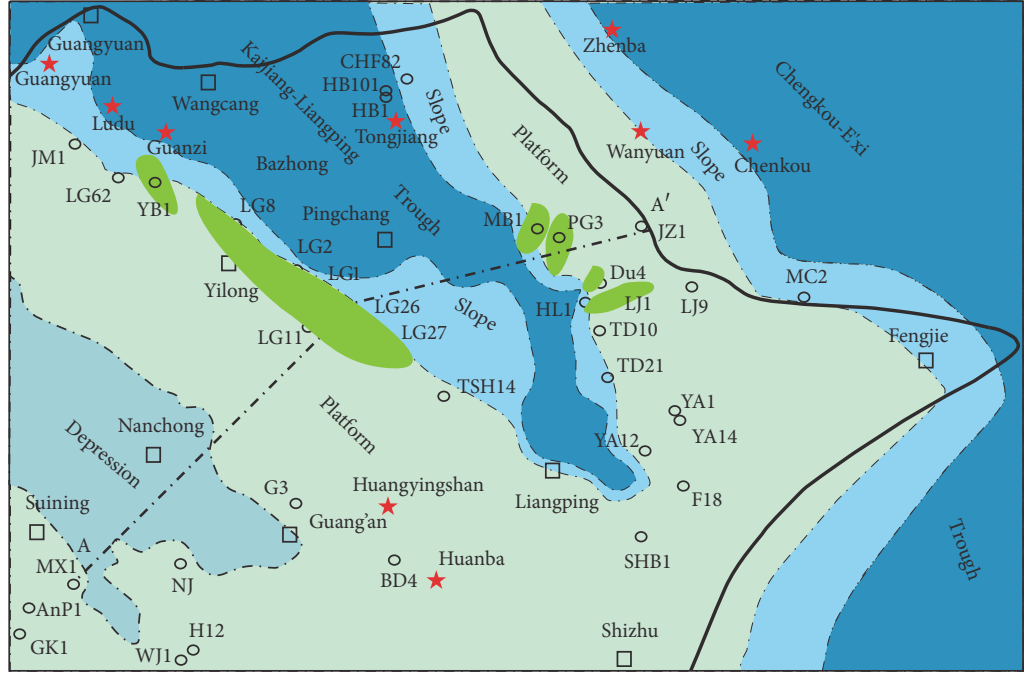

(a)

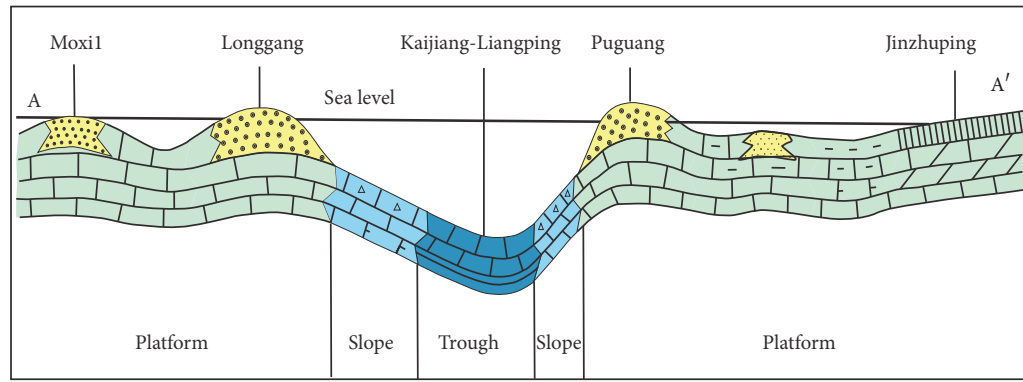

(b)

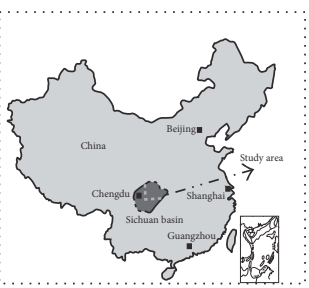

\begin{tabular}{|c|c|}
\hline . & Coal \\
\hline 甚界 & Gypsum \\
\hline-- & Mudstone \\
\hline 0 & Well location \\
\hline$\star$ & Section location \\
\hline
\end{tabular}

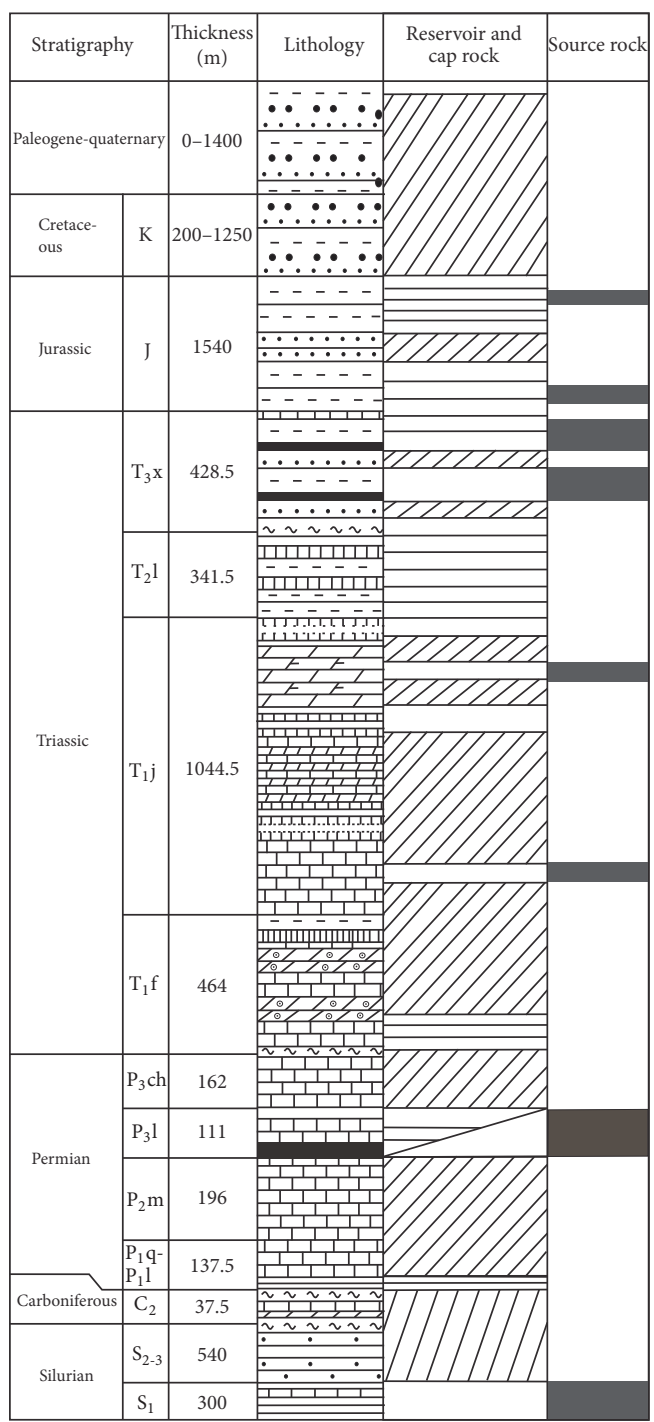

(c)

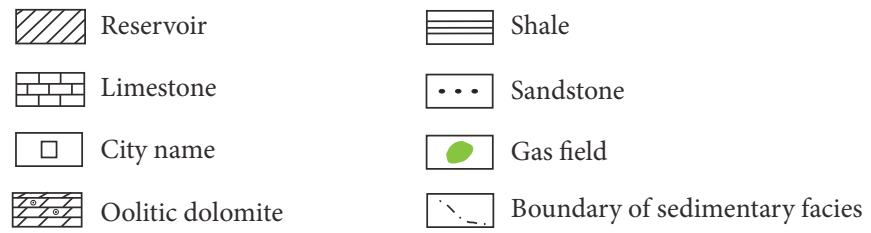

FIGURE 1: Diagrams showing (a) location of major gas fields, (b) distribution of sediment facies during the Changxing-Feixianguan deposition period, and (c) generalized stratigraphy. Possible source rock and reservoir intervals are marked. (Modified from Hu et al. (2014) [19].)

shallower during the period of middle and upper Longmaxi with lower TOC [31].

Lower Cambrian black shale and mudstone have cumulative thickness of $180 \mathrm{~m}$ to $200 \mathrm{~m}, 20 \mathrm{~m}$ to $100 \mathrm{~m}$ of which are sediments with TOC $>1 \%$ in the Shatan-Nangjiang area. Toward the east around the Wuxi area, the thickness increases to $150 \mathrm{~m}$ to $180 \mathrm{~m}$ [32]. The depositional environment was changed from a shallow inner shelf to deep shelf. $\mathrm{ER}_{o}$ calculated from $R_{b}$ for the organic matter is higher than $2.5 \%$ (Liang and Chen, 2005) [24].

\section{Experimental}

3.1. Samples. Twenty-one outcrop source rock samples were collected from Ludu, Guanzi, Tongjiang, Huayingshan, Zhenba, and Wangyuan in the north Sichuan. Seven source 
rock samples were taken from well-cuttings in Huayingshan and the $\mathrm{HB}$ and $\mathrm{YB}$ gas fields (Figure 1). The twenty-eight samples represent potential source rocks for the gas and solid bitumen in the NE Sichuan gas fields, of which twelve were measured for $R_{b}$ or $R_{o}$, twenty-two for biomarker composition using GC-MS, ten for Rock Eval pyrolysis, and nine for pyrite sulfur isotopes.

Twenty bitumen samples were obtained from the Lower Triassic Feixianguan Fm $\left(\mathrm{T}_{1} \mathrm{f}\right)$ and Upper Permian Changxing $\mathrm{Fm}\left(\mathrm{P}_{3} \mathrm{ch}\right)$ from $\mathrm{MB}, \mathrm{PG}, \mathrm{LJ}, \mathrm{Du}, \mathrm{Po}, \mathrm{YA}$, and TD gas fields in the east to the PG gas field and YB, LG, and HB gas fields in the west to the PG gas field, northern Sichuan Basin (Figure 1), and were analyzed for biomarker composition using GC-MS. Among these samples, three in association with $\mathrm{H}_{2} \mathrm{~S}<0.5 \%$ in gas composition were analyzed for carbon isotopes.

\subsection{Analytical Methods}

3.2.1. Biological Markers. About $120 \mathrm{~g}$ source rock samples were powered for 3 minutes using a grinding machine and then Soxhlet extracted using dichloromethane (DCM) for 72 hours. Source rock extracts were weighed and then deasphalted using a 40x excess of hexane. All of the deasphalted samples were fractionated on a silica: alumina column chromatography using $n$-pentane, dichloromethane (DCM), and methanol as developing solvents to yield the saturated, aromatic, resin (NSO) fraction, respectively. The saturated and aromatic hydrocarbon fractions were analyzed separately using a Hewlett Packard 6890GC/5973MSD-mass spectrometer. The gas chromatograph (GC) was fitted with a HP-5MS capillary column $(30 \mathrm{~m} \times 0.25 \mathrm{~mm} \times 0.25 \mu \mathrm{m})$. The temperature of sample injection was $300^{\circ} \mathrm{C}$ and the oven was held at $50^{\circ} \mathrm{C}$ for $1 \mathrm{~min}$. The temperature was then increased from $50^{\circ} \mathrm{C}$ to $310^{\circ} \mathrm{C}$ at a rate of $3^{\circ} \mathrm{C} / \mathrm{min}$ and then held at $310^{\circ} \mathrm{C}$ for $18 \mathrm{~min}$. Helium was used as a carrier gas $(1.0 \mathrm{~mL} / \mathrm{min})$. Operating conditions were ion source, $230^{\circ} \mathrm{C}$; emission current, $34.6 \mu \mathrm{A}$; quadruple temperature, $150^{\circ} \mathrm{C}$; and electron energy, $70 \mathrm{eV}$.

Identification of aryl isoprenoids was achieved through analysis of mass spectra, retention time, and comparison with literature data [33-36].

3.2.2. Vitrinite and Bitumen Reflectance Measurement. Vitrinite and bitumen reflectance were measured on MPVIII microphotometer 12213 using the Chinese standard SY/T5124-1995. The values are reported using an average of more than 15 measurements.

3.2.3. Pyrite $\delta^{34} S$ Measurement. Pyrite sulfur was released from mudstones or shales by adding a mixture of hot $6 \mathrm{~N}$ $\mathrm{HCl}$ and $\mathrm{CrCl}_{2}$ under $\mathrm{N}_{2}$ with a gas flow carrying the $\mathrm{H}_{2} \mathrm{~S}$ to a trap where it was recovered as $\mathrm{Ag}_{2} \mathrm{~S}$. The $\mathrm{Ag}_{2} \mathrm{~S}$ precipitate was analyzed for $\mathrm{S}$-isotope at the Institute of Geology and Geophysics, Chinese Academy of Sciences (IGGCAS), on a Finnigan Delta $S$ gas source mass spectrometer. Sulfur isotope results are generally reproducible within $\pm 0.3 \%$.
3.2.4. Separation and $\delta^{13} C$ and $\delta^{34} S$ Measurement of Kerogen and Solid Bitumen. The methods for separation and $\delta^{34} \mathrm{~S}$ measurement of kerogen and solid bitumen were reported previously [15]. Fresh rock samples were finely ground and treated with hot $6 \mathrm{~N} \mathrm{HCl}$, a mixture of $6 \mathrm{~N} \mathrm{HCl}$ and $40 \% \mathrm{HF}$, and then $6 \mathrm{~N} \mathrm{HCl}$, to dissolve minerals. Pyrite was further removed from the remaining kerogen or solid bitumen by adding a mixture of hot $6 \mathrm{~N} \mathrm{HCl}$ and $\mathrm{CrCl}_{2}$ under $\mathrm{N}_{2}$ with a gas flow carrying the $\mathrm{H}_{2} \mathrm{~S}$ to a trap where it was recovered as $\mathrm{Ag}_{2} \mathrm{~S}$. After dilution with distilled water and centrifugation, the remaining solid bitumen or kerogen was separated from the residue (precipitate) using heavy liquids $(\mathrm{KBr}+\mathrm{ZnBr})$ with density of 1.8 to $1.9 \mathrm{~g} / \mathrm{cm}^{3}$ and of 2.0 to $2.1 \mathrm{~g} / \mathrm{cm}^{3}$, respectively. The residual kerogen and solid bitumen were collected and reground to expose new pyrite surfaces and the whole procedure was repeated once more. After the two treatments, the residual kerogen or solid bitumen was further analyzed using X-ray diffraction (XRD) to determine whether pyrite was below the detection limits $(\leq 0.5 \%$ depending on conditions). If not, additional treatments were made.

For organic carbon analysis, about $5 \mathrm{mg}$ dry kerogen or solid bitumen was combusted at $850^{\circ} \mathrm{C}$ to collect $\mathrm{CO}_{2}$. Isotope ratio measurements were carried out with a Thermo Delta $S$ mass spectrometer, calibrated with a series of IAEA standards (IAEA-600, $\delta^{13} \mathrm{C}=-27.771 \%$, VPDB). Results are presented as $\delta^{13} \mathrm{C}$ values relative to the VPDB standard. The reproducibility for measurement was $\pm 0.2 \%$.

For organic sulfur analysis, about 350 to $900 \mathrm{mg}$ dry kerogen or solid bitumen was combusted in a Parr bomb at ca. $25 \mathrm{~atm} \mathrm{O}_{2}$ to oxidize organically bound sulfide to sulfate. Dissolved sulfate was precipitated as $\mathrm{BaSO}_{4}$. This procedure was done only when the residual kerogen samples contained pyrite sulfur/total sulfur $<0.08$. The maximum amount of pyrite present after the chromium reduction was determined by measuring the dissolved iron at $\mathrm{pH}<2$ using an atomic absorption spectrometer (assuming that all $\mathrm{Fe}$ occurs as pyrite in the kerogen). This process guarantees that the $\mathrm{BaSO}_{4}$ analyzed for $\delta^{34} \mathrm{~S}$ mostly reflects the organic sulfur in the kerogen, with the absolute error depending on the difference in $\delta^{34} \mathrm{~S}$ value between the kerogen and associated pyrite. $\mathrm{BaSO}_{4}$ was directly decomposed to $\mathrm{SO}_{2}$ by heating at $1700^{\circ} \mathrm{C}$ in a quartz tube for isotopic analysis using the method of Bailey and Smith [37]. Isotopic determinations were carried out on a Thermo Delta $S$ mass spectrometer by comparing with an internal standard SA1 $\left(\delta^{34} S=15.15 \%\right.$, VPDB $)$ and calibrated by a series of IAEA standards. Results are presented as $\delta^{34}$ S relative to the Vienna Canyon Diablo Troilite (VCDT). The reproducibility for $\delta^{34} S$ measurement is $\pm 0.3 \%$.

\section{Results}

4.1. Vitrinite or Bitumen Reflectance, Rock Eval Pyrolysis, and EOM/TOC Ratios of the Potential Source Rocks. The Cambrian shales have $R_{b}$ about $4.2 \%$ or equivalent vitrinite reflectance $\left(\mathrm{ER}_{o}\right)$ of $3.0 \%(n=2)\left(\mathrm{ER}_{o}=0.618 R_{b}+0.40\right.$; [17]), the Lower Silurian and Upper Ordovician have $R_{b}$ from 2.0 to $2.9 \%$ or $\mathrm{ER}_{o}$ of $1.6 \%$ to $2.2 \%(n=6)$, and the lowest $R_{b}$ 
TABLE 1: Potential source rock TOC and aryl isoprenoids (AI), its kerogen vitrinite reflectance $R_{o}$, and $\mathrm{S} / \mathrm{C}$ atomic ratio and $\delta^{13} \mathrm{C}$ and $\delta^{34} \mathrm{~S}$ values.

\begin{tabular}{|c|c|c|c|c|c|c|c|c|c|c|}
\hline Area & Sample number & Age & Depth (m) & Lithology & $\operatorname{TOC}^{\mathrm{a}}(\%)$ & $R_{b} / \mathrm{ER}_{o}(\%)$ & $\mathrm{AI}$ & $\delta^{13} \mathrm{C}^{\mathrm{a}}$ & $\delta^{34} S_{\mathrm{ke}}{ }^{\mathrm{a}}$ & $\delta^{34} \mathrm{~S}_{\mathrm{py}}$ \\
\hline \multirow{2}{*}{ Tongjiang } & TJ7-60 & Cam. & Otc & Black shale & 2.17 & $4.2 / 3.0$ & $\mathrm{X}$ & - & - & - \\
\hline & TJ7-153 & Cam. & Otc & Black shale & 2.35 & $4.3 / 3.1$ & $\mathrm{X}$ & -31.9 & 3.5 & - \\
\hline Wanyuan & ZB19 & Cam. & Otc & Black shale & 5.26 & - & $\mathrm{X}$ & -30.7 & 14.5 & 13.5 \\
\hline \multirow{4}{*}{ Huayinshan } & HYS-3 & $\mathrm{O}_{3} \mathrm{w}$ & Otc & Siliceous shale & 2.63 & $2.0 / 1.6$ & $\mathrm{X}$ & -30.0 & 7.5 & -3.2 \\
\hline & HYS-6 & $\mathrm{S}_{1} \mathrm{l}$ & Otc & Black shale & 8.72 & $2.1 / 1.7$ & $\checkmark$ & -28.7 & 15.9 & - \\
\hline & HYS-8 & $S_{1} l$ & Otc & Black shale & 1.96 & - & $\checkmark$ & -29.1 & -0.4 & - \\
\hline & HYS-11 & $\mathrm{S}_{1} 1$ & Otc & Black shale & 1.99 & - & $\checkmark$ & -29.5 & 5.3 & - \\
\hline Guanba & Guanba & $\mathrm{S}_{1}$ & Otc & Black shale & - & - & $\mathrm{X}$ & - & 7.2 & - \\
\hline Shiniulan & Shiniulan & $\mathrm{S}_{1}$ & Otc & Black shale & - & - & $\mathrm{X}$ & - & 6.8 & -4.3 \\
\hline Chengkou & ZB21 & $\mathrm{S}_{1} \mathrm{l}$ & Otc & Black shale & - & $2.9 / 2.2$ & $\mathrm{X}$ & -29.7 & -4.4 & -3.9 \\
\hline Tongjiang & TJ7-104 & $\mathrm{S}_{1} 1$ & Otc & Black shale & - & $2.8 / 2.1$ & $\checkmark$ & -30.8 & 1.9 & - \\
\hline $\mathrm{HB}$ & HB1 & $\mathrm{P}_{3} \mathrm{l}$ & $5662 \sim 5713$ & Black mudstone & 1.5 & - & - & -27.8 & -26.7 & - \\
\hline \multirow{2}{*}{ PG } & PG5 & $\mathrm{P}_{3} \mathrm{l}$ & $5586 \sim 5747$ & Mudstone & - & - & - & $-27.5^{*}$ & - & - \\
\hline & PG5 & $\mathrm{P}_{3} 1$ & $4891 \sim 5157$ & Cal. mudstone & - & - & - & $-27.6^{*}$ & - & - \\
\hline JX & $\mathrm{JX} 1$ & $\mathrm{P}_{3} \mathrm{l}$ & $4727 \sim 4763$ & Cal. mudstone & - & - & - & $-27.0^{*}$ & - & - \\
\hline YB & YB3 & $\mathrm{P}_{3} \mathrm{l}$ & $7123 \sim 7203$ & Cal. mudstone & - & - & - & -26.8 & - & - \\
\hline Zhenba & ZB-09-01 & $\mathrm{P}_{3} \mathrm{l}$ & Otc & Black limestone & 1.21 & - & - & -27.6 & 0.1 & - \\
\hline \multirow{5}{*}{ Huayinshan } & $10-\mathrm{VI}-4$ & $\mathrm{P}_{3} \mathrm{l}$ & 333.5 & Black mudstone & 3.11 & $/ 1.7$ & $\mathrm{X}$ & -24.2 & - & - \\
\hline & 10-VI-16 & $\mathrm{P}_{3} \mathrm{l}$ & 363.5 & Black mudstone & 1.26 & - & $\mathrm{X}$ & -28.1 & 4.1 & - \\
\hline & $10-\mathrm{VI}-30$ & $\mathrm{P}_{3} \mathrm{l}$ & 413.8 & Black mudstone & 1.96 & $/ 1.7$ & $\mathrm{X}$ & -23.2 & - & - \\
\hline & $10-\mathrm{VI}-40$ & $\mathrm{P}_{3} 1$ & 446.3 & Black mudstone & 2.46 & - & $\mathrm{X}$ & -23.0 & 0.6 & - \\
\hline & 10-VI-56 & $\mathrm{P}_{3} \mathrm{l}$ & 482.6 & Black mudstone & 4.33 & $/ 1.7$ & $\mathrm{X}$ & -22.7 & -6.6 & -14.8 \\
\hline Ludu & LDI-7 & $\mathrm{P}_{3} \mathrm{~d}$ & Otc & Black mudstone & 4.83 & - & $\checkmark$ & -27.1 & - & - \\
\hline Zhenba & ZB14-1 & $\mathrm{P}_{3} \mathrm{~d}$ & Otc & Black chert & 7.20 & $2.2 / 1.8$ & $\mathrm{X}$ & -26.5 & -1.7 & -21.3 \\
\hline Wangyuan & ZB17-3 & $\mathrm{P}_{3} \mathrm{~d}$ & Otc & Black shale & 3.59 & $/ 1.8$ & $\mathrm{X}$ & -26.4 & 5.5 & -21.4 \\
\hline \multirow{2}{*}{ Guanzi } & GZ17 & $\mathrm{P}_{3} \mathrm{~d}$ & Otc & Black shale & - & - & $\checkmark$ & -27.2 & -27.1 & -32.6 \\
\hline & GZ18 & $\mathrm{P}_{3} \mathrm{~d}$ & Otc & Black shale & - & - & $\checkmark$ & -26.5 & -30.6 & -34.5 \\
\hline CJG & CJ43 & $\mathrm{P}_{3} \mathrm{~d}$ & Otc & Black shale & 0.33 & $0.7 / 0.8$ & $\checkmark$ & -27.2 & - & - \\
\hline
\end{tabular}

-: no data available; ${ }^{a}$ from Cai et al. [12]; ${ }^{*}$ from Borjigen et al. [4]; X: no; $\checkmark$ : yes. $\delta^{34} S_{\text {ke }}$ and $\delta^{34} S_{\text {py }}$ : kerogen and pyrite $\delta^{34}$ S; cal.: calcareous; CJG: Changjianggou; equivalent vitrinite reflectance $\mathrm{ER}_{o}=0.618 R_{b}+0.40$ [17].

occurs in the Upper Permian Dalong Fm chert (Table 1). The Upper Permian Longtan Fm and Dalong Fm yielded vitrinite reflectance values of about $1.7 \%(n=4)$. ER $\mathrm{E}_{o}$ and $R_{b}$ values show decrease toward younger strata. The results are similar to those from Fu et al. [17].

Based on Rock Eval pyrolysis $T_{\max }$ and hydrogen index (HI) relationship [38], Upper Permian Dalong Fm mudstone and shale are oil-prone kerogen ranging from marginally mature, with $T_{\max }$ from about $430^{\circ} \mathrm{C}$ and $\mathrm{HI}$ from 120 to $300 \mathrm{mg} \mathrm{HC/g}$ TOC for samples CJ43 and CJ36, to highly mature with $T_{\max }$ from $467^{\circ} \mathrm{C}$ to $540^{\circ} \mathrm{C}$ and $\mathrm{HI}$ of 4 to $52 \mathrm{mg}$ $\mathrm{HC} / \mathrm{g}$ TOC for four other samples (Table 2). The organic matter from Upper Permian Wujiaping Fm, Lower Silurian Longmaxi Fm, and Lower Cambrian shales is overmature and has $T_{\max }$ of about $603^{\circ} \mathrm{C}$ and $\mathrm{HI}$ less than $10 \mathrm{mg} \mathrm{HC} / \mathrm{g}$ TOC. This feature is consistent with the very low S1 values or free hydrocarbons contents from 0.01 to $0.04 \mathrm{mg} \mathrm{HC/g}$ rock for the samples (Table 2).

Extracted organic matter (EOM) from the black mudstone and shale ranges from 19 to $622 \mathrm{ppm}(n=19)$, and $\mathrm{EOM} / \mathrm{TOC}$ ratios range from $0.03 \%$ to $1.67 \%(n=18)$
(Table 3). All the Silurian, Ordovician, and Cambrian samples show EOM/TOC less than $0.8 \%$ and the Upper Permian samples show much higher values.

4.2. Potential Source Rock Biomarkers. Organic matter extracted from Lower Silurian Longmaxi Fm, Upper Permian Longtan Fm, and Dalong Fm source rocks shows very similar distributions of 191 and 217 traces, including abundant gammacerane, and " $V$ " shape in the distribution of $\mathrm{C}_{27}-\mathrm{C}_{29}$ regular steranes (Figure 2). The high percentages of $\mathrm{C}_{29}$ steranes detected from the Silurian and Cambrian are attributed to algae such as benthic brown algae or macro algae, acritarchs, cryptospores, and arthropods, rather than a terrestrial origin ([15] and references therein). The majority of the analyzed samples show $\mathrm{C}_{29} / \mathrm{C}_{30} 17 \alpha, 21 \beta$-hopane ratio $<0.8$ and $\mathrm{C}_{23}$ tricyclic terpane/ $\mathrm{C}_{30} 17 \alpha, 21 \beta$-hopane ratio < 0.3 (Table 3).

Among maturity-related parameters, $\mathrm{C}_{29} \alpha \alpha \alpha$ sterane $20 \mathrm{~S} /(20 \mathrm{~S}+20 \mathrm{R})$ ratios range from 0.47 to 0.58 (Table 3 ), being mostly close to the equilibrium value of 0.55 , suggesting that the source rocks are mature to overmature, commensurate 
TABLE 2: Rock Eval pyrolysis data of the potential source rocks.

\begin{tabular}{lcccccccccc}
\hline Sample number & Age & $\mathrm{S}_{1}(\mathrm{mg} / \mathrm{g})$ & $\mathrm{S}_{2}(\mathrm{mg} / \mathrm{g})$ & $\mathrm{S}_{1} /\left(\mathrm{S}_{1}+\mathrm{S}_{2}\right)$ & $\mathrm{S}_{1}+\mathrm{S}_{2}$ & $T_{\max }\left({ }^{\circ} \mathrm{C}\right)$ & $\mathrm{S}_{3}(\mathrm{mg} / \mathrm{g})$ & $\mathrm{TOC}(\%)$ & $\mathrm{HI}$ & $\mathrm{OI}$ \\
\hline ZB-19 & $\mathrm{Cam}$ & 0.01 & 0.04 & 0.20 & 0.05 & 605 & 0.15 & 5.3 & 0.76 & 2.9 \\
ZB-21 & $\mathrm{S}_{1} \mathrm{l}$ & 0.04 & 0.33 & 0.11 & 0.37 & 603 & 0.16 & 6.0 & 5.5 & 2.7 \\
ZB-09-01 & $\mathrm{P}_{3} \mathrm{w}$ & 0.02 & 0.09 & 0.18 & 0.11 & 605 & 0.49 & 1.2 & 7.4 & 40 \\
GZ-15 & $\mathrm{P}_{3} \mathrm{w}$ & 0.04 & 1.33 & 0.03 & 0.03 & 603 & 0.44 & 15.7 & 8.5 & 2.8 \\
ZB-14-01 & $\mathrm{P}_{3} \mathrm{~d}$ & 0.26 & 2.30 & 0.10 & 2.56 & 477 & 0.35 & 7.2 & 32 & 4.9 \\
ZB-17-03 & $\mathrm{P}_{3} \mathrm{~d}$ & 0.21 & 1.81 & 0.10 & 2.02 & 469 & 0.14 & 3.6 & 50 & 3.9 \\
LD-7 & $\mathrm{P}_{3} \mathrm{~d}$ & 0.01 & 0.21 & 0.05 & 0.22 & 540 & - & 4.8 & 4.3 & - \\
LD-10 & $\mathrm{P}_{3} \mathrm{~d}$ & 0.02 & 0.12 & 0.14 & 0.14 & 530 & - & 2.3 & 52 & - \\
CJ-36 & $\mathrm{P}_{3} \mathrm{~d}$ & 0.14 & 14.02 & 0.01 & 0.01 & 436 & 6.00 & 11.1 & 126 & 54 \\
CJ-43 & $\mathrm{P}_{3} \mathrm{~d}$ & 0.06 & 0.98 & 0.06 & 0.06 & 429 & 0.20 & 0.33 & 297 & 61 \\
\hline
\end{tabular}

$T_{\max }$ : temperature of maximum of S2 peak; S1: liquid hydrocarbon potential; S2: residual petroleum potential; PI: production index $\mathrm{S}_{1} /\left(\mathrm{S}_{1}+\mathrm{S}_{2}\right) ; \mathrm{HI}$ : hydrogen index, in mg HC/g TOC; OI: oxygen index, in mg HC/g TOC.

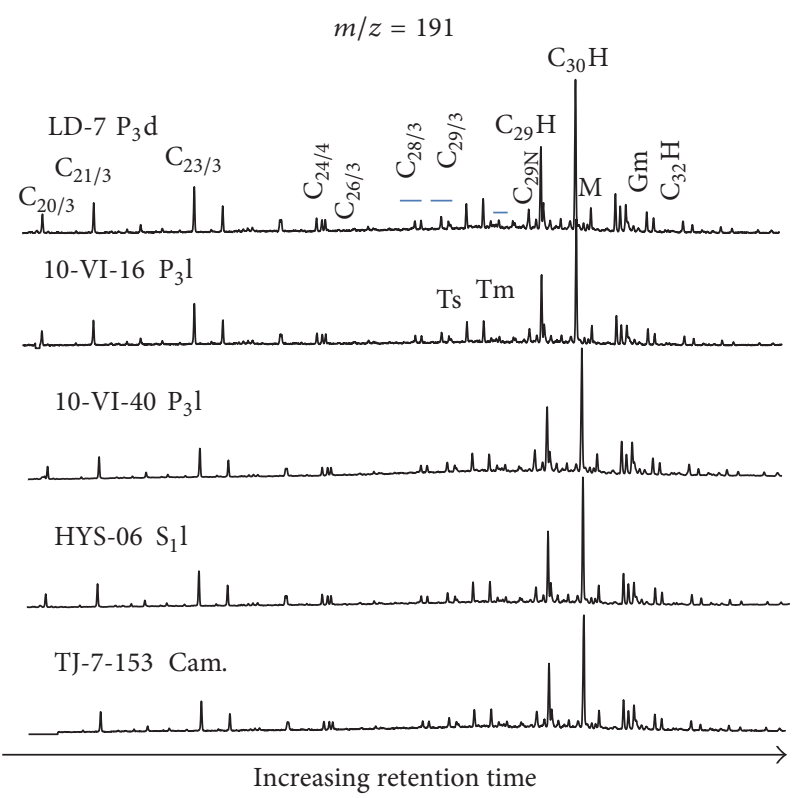

(a)

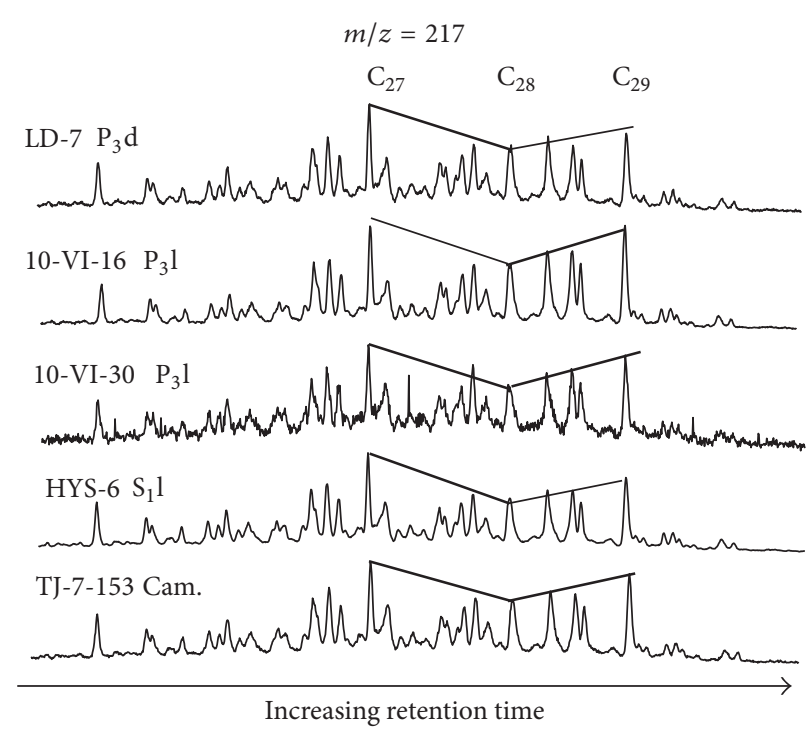

(b)

FIGURE 2: Partial GC-MS chromatograms $(m / z=191$ and 217) for extractable organic matter from the Upper Permian Dalong Fm (LD-7) and Longtan Fm (10-VI-16, 10-VI-40), Lower Silurian (HYS-06), and Lower Cambrian (TJ-7-153) (28/3 is $\mathrm{C}_{28}$ tricyclic terpane and M is moretane; see note in Table 3 for other abbreviations).

with the $R_{o}$ or $R_{b}$ values. Ts/(Ts $\left.+\mathrm{Tm}\right)$ ratios range from 0.30 to 0.52 and $\mathrm{C}_{29} \mathrm{Ts} /\left(\mathrm{C}_{29} \mathrm{Ts}+\mathrm{C}_{29} \mathrm{H}\right)$ from 0.11 to 0.30 . Similar case was reported from the Cambrian overmature source rocks in the Tarim Basin with $\mathrm{Ts} /(\mathrm{Ts}+\mathrm{Tm})$ ratios from 0.21 to 0.49 ( $n=12$; $[15,39]$; (Li et al., 2010)); thus other factors such as lithology, Eh, and pH during the deposition besides maturity may have effects on these ratios $[15,39,40]$.

There exist no significant differences in part of biological precursor- and/or environment- related parameters for the four suites of the source rocks. The analyzed samples have $\mathrm{Pr} / \mathrm{Ph}$ ratios from 0.53 to 1.17 , and $\mathrm{C}_{35} / \mathrm{C}_{34}$ hopane ratios are mainly greater than 0.5 , indicating reduced depositional environments. All analyzed samples have $\mathrm{C}_{24}$ tetracyclic terpane/ $\mathrm{C}_{26}$ tricyclic terpane ratio $<0.7$ and $\mathrm{C}_{29} / \mathrm{C}_{30}$ hopane ratio $<0.8$. The values are consistent with shale/mudstone rather than carbonate depositional environments [41]. The analyzed samples have $\sum \mathrm{C}_{27}-\mathrm{C}_{29}$ regular steranes/ $\sum \mathrm{C}_{29}-\mathrm{C}_{33}$ $17 \alpha$-hopanes ratios from 0.33 to 0.85 and gammacerane $/ C_{30}$ $17 \alpha, 21 \beta$-hopane ratios from 0.12 to 0.37 with slightly higher values in $\mathrm{P}_{3}$ l source rocks (Table 3 ). Compared with other suites of the source rocks, $\mathrm{P}_{3} \mathrm{~d}$ source rocks show relatively high $\mathrm{C}_{27} / \sum \mathrm{C}_{27}-\mathrm{C}_{29}$ regular steranes ratios (Table 3 ).

Interestingly, $\mathrm{P}_{3} 1$ source rock sample $10-\mathrm{VI}-16$ shows significantly higher $\sum \mathrm{C}_{27}-\mathrm{C}_{29}$ regular steranes/ $\sum \mathrm{C}_{29}-\mathrm{C}_{33}$ $17 \alpha$-hopanes ratios and lower $\delta^{13} \mathrm{C}$ values of kerogen than four other $\mathrm{P}_{3} 1$ source rock samples from the same well 10-VI (Tables 1 and 4).

A pseudo homologous series of aryl isoprenoids were revealed from mass chromatograms of $\mathrm{m} / z 133$ in the Upper Permian Dalong Fm and some Silurian source rocks 


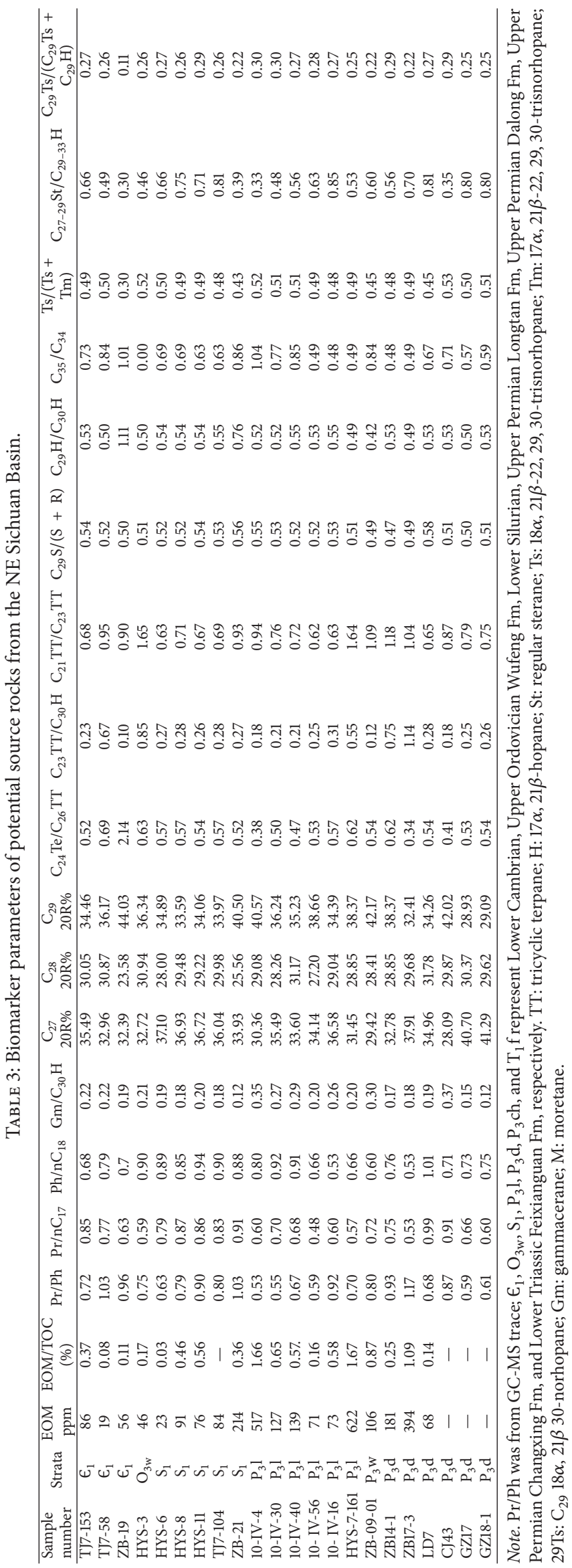




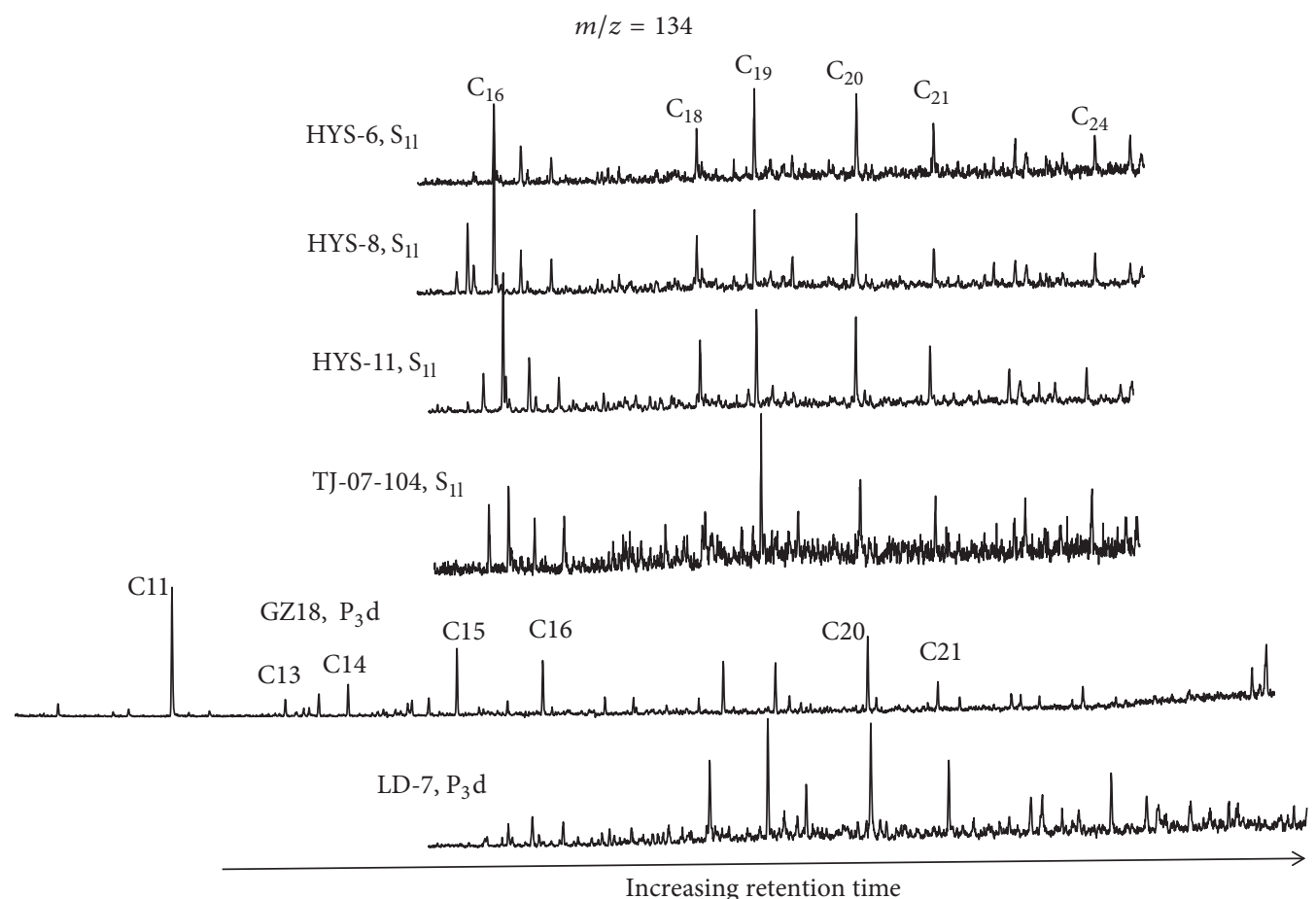

FIGURE 3: GC-MS selected ion mass chromatograms $(m / z$ 134) for extractable organic matter from source rocks from Lower Silurian (HYS-6, HYS-8, HYS-11, and TJ-07-104) and Upper Permian (GZ18 and LD-7) showing abundant aryl isoprenoids.

(samples HYS-6, HYS-8, HYS-11, and TJ-7-104, but not from Guanba, Shiniulan, and ZB21, Figure 3 and Table 1). The major components possess the 2, 3,6-trimethyl substituted pattern with a predominance of $\mathrm{C}_{16}-\mathrm{C}_{24}$ homologues. The aryl isoprenoids were considered to result from aromatic carotenoids of the green sulfur bacteria (Chlorobiaceae) [33$35,42,43]$. However, a North Sea oil has been found to have aryl isoprenoids derived from mixtures of $\mathrm{C}-\mathrm{C}$ bond cleavage of isorenieratanes and $\beta$-isorenieratanes derived from aromatisation of $\beta$-carotene; thus green sulfur bacteria Chlorobiaceae are not the unique source of the aryl isoprenoids [44]. No aryl isoprenoids were detected in the samples analyzed from the Cambrian and Upper Permian Longtan Fm.

4.3. Molecular Composition of Extractable Organic Matter of Solid Bitumen. Organic matter extracted from Feixianguan Fm and Changxing Fm solid bitumen from wells HB101 and YB101 in western gas fields and wells TD10 and Du4 in eastern gas fields and PL-37 outcrop yield highly similar distribution in 191 and 217 traces, including abundant gammacerane and "V" shape in the distribution of $\mathrm{C}_{27}-\mathrm{C}_{29}$ regular steranes (Figure 4; Table 4). Organic matter extracted from solid bitumen samples has $\mathrm{C}_{29} \alpha \alpha \alpha$ sterane $20 \mathrm{~S} /(20 \mathrm{~S}+20 \mathrm{R})$ ratios from 0.50 to 0.58 (Table 4 ), being close to the equilibrium value. The samples have $\mathrm{Ts} /(\mathrm{Ts}+\mathrm{Tm})$ ratios from 0.47 to 0.59 and $\mathrm{C}_{29} \mathrm{Ts} /\left(\mathrm{C}_{29} \mathrm{Ts}+\mathrm{C}_{29} \mathrm{H}\right)$ from 0.25 to 0.31 . The bitumen samples have $\mathrm{Pr} / \mathrm{Ph}$ ratios from 0.41 to 0.88 and $\mathrm{C}_{27} \alpha \alpha \alpha 20 \mathrm{R}$ sterane $>\mathrm{C}_{28} \alpha \alpha \alpha 20 \mathrm{R}<\mathrm{C}_{29} \alpha \alpha \alpha$ 20R (Table 4). All the values of the parameters are similar to most of the source rocks analyzed except the bitumen from wells LG11, LJ2, HL5 (sample HL5-4), and PG2 (sample PG2-3) showing higher $\mathrm{C}_{35} / \mathrm{C}_{34}$ hopane ratios $(>1.0)$.

Interestingly, $\mathrm{C}_{16}-\mathrm{C}_{23}$ aryl isoprenoids were detected from extracts from solid bitumen from wells HB101, LG82, and YB101 in the western gas fields (Figure 5). No aryl isoprenoids were detected from the solid bitumen from wells in the east, such as TD10, YA1, TS5, PG11, and MB4.

4.4. Potential Source Rock Kerogen and Pyrite $\delta^{34} S$ Values and Their Changing Trend. A pyrite from Lower Cambrian black shale was measured to have $\delta^{34} \mathrm{~S}$ value of $13.5 \%$. The value is heavier than those of two pyrite samples from Upper Ordovician Wufeng Fm and Lower Silurian Longmaxi Fm mudstone and shale with $\delta^{34} \mathrm{~S}$ value of $-3.2 \%$ and $-4.3 \%$, respectively (Table 1). A much lighter $\delta^{34} S$ value of $-14.8 \%$ was measured from Longtan Formation mudstone pyrite and the lightest values from $-21.3 \%$ to $-34.5 \%$ o $(n=4)$ were measured with an average of $-27.5 \%$ in the Dalong Formation mudstone pyrites. That is, the pyrite $\delta^{34} S$ values show negative shift from early Cambrian to the latest Permian. The changing trend is similar to the kerogen $\delta^{34} \mathrm{~S}$ values from $3.5 \%$ to $14.5 \%$ o $(n=2)$ in the Lower Cambrian, $-4.4 \%$ o to $15.9 \%$ o $(n=8)$ with an average of 5.0\%o in the Upper Ordovician and Lower Silurian, $-6.6 \%$ to $4.1 \%$ with an average of $-0.45 \%$ in the Upper Permian Longtan Formation, and $-30.6 \%$ to $5.5 \%$ o $(n=4)$ with an average of $-14.5 \%$ in the Upper Permian Dalong Formation in the Lu, Wangyuan, Guanzi, and CJG outcrops. 


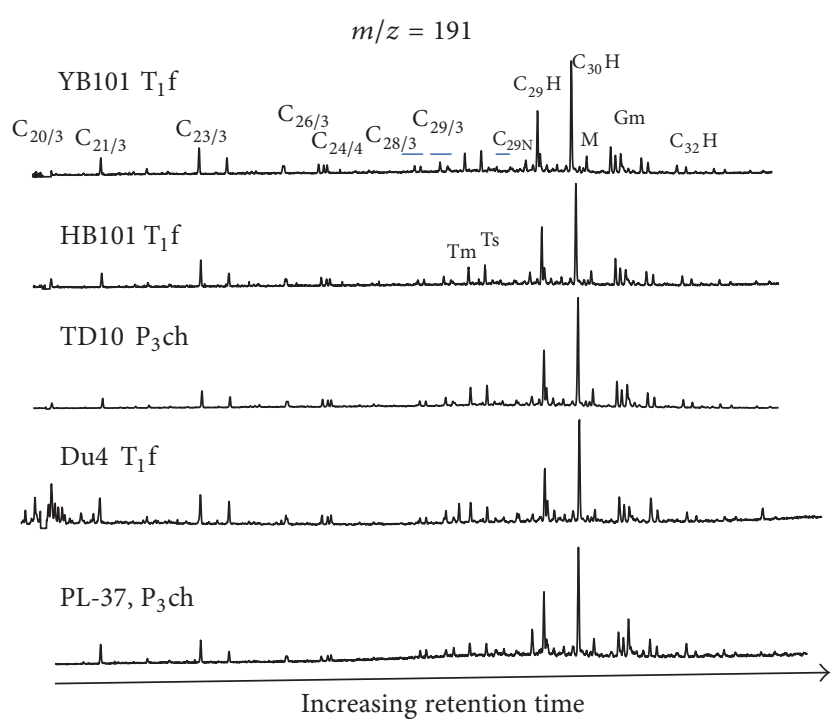

FIGURE 4: Partial GC-MS chromatograms $(m / z=191)$ for extractable organic matter from solid bitumen samples.

4.5. Solid Bitumen $\delta^{13} C$ and $\delta^{34} S$ Values. Three solid bitumen samples from wells LG82, LG11, and HB101 in the western gas fields were associated with $\mathrm{H}_{2} \mathrm{~S}<0.5 \%$ in gas composition and were measured to have $\delta^{13} \mathrm{C}$ values from -25.1 to $-26.7 \%$ $(n=3)$. The values are similar to the two previously reported values of -26.5 and $-27.3 \%$ (Table 5 ). The $\delta^{13} \mathrm{C}$ values are within the range of the $\mathrm{P}_{3} \mathrm{~d}$ and $\mathrm{P}_{3} 1$ kerogens and significantly heavier than the $\mathrm{O}_{3} \mathrm{w}$ and $\mathrm{S}_{1} 1$ kerogens and the Cambrian kerogens (Figure 6(a)). The two kerogen samples have $\delta^{34} S$ values of $9.6 \%$ and $5.8 \%$, which are close to the heavier values of the $\mathrm{P}_{3} \mathrm{~d}$ kerogens and the $\mathrm{P}_{3} \mathrm{w}$ and $\mathrm{P}_{3} 1$ kerogens (Figure 6(b)).

\section{Discussion}

5.1. Source Rock Depositional Environment: Kerogen $\delta^{34} S$ Values and Aryl Isoprenoids. Samples from the Cambrian, Silurian, and Upper Permian Longtan Fm with $R_{o}$ higher than $1.7 \%$ yield very low EOM/TOC and $S_{1}$ (Tables 1 and 3). Saturated biomarkers and aryl isoprenoids were detected at correspondingly low levels. An obvious question to be addressed is whether the EOM within these overmature samples is syngenetic, migrated petroleum, or contaminants. Although it is impossible to prove that these compounds are syngenetic, their occurrence and distributions are consistent with other observations. Aryl isoprenoids have been detected in the Tarim Basin from the Cambrian overmature anoxic source rocks and highly mature oils derived from these sources, although their concentrations and carbon number decrease with increasing maturity $[13,15,16,42,45]$. The NE Sichuan Basin study area is similar to the Tarim Basin in that both are characterized by rapid burial $[6,8,12,23]$; thus, some molecular markers in the study area may be related to the deposition environment and/or OM sources although it is hard to be proved.

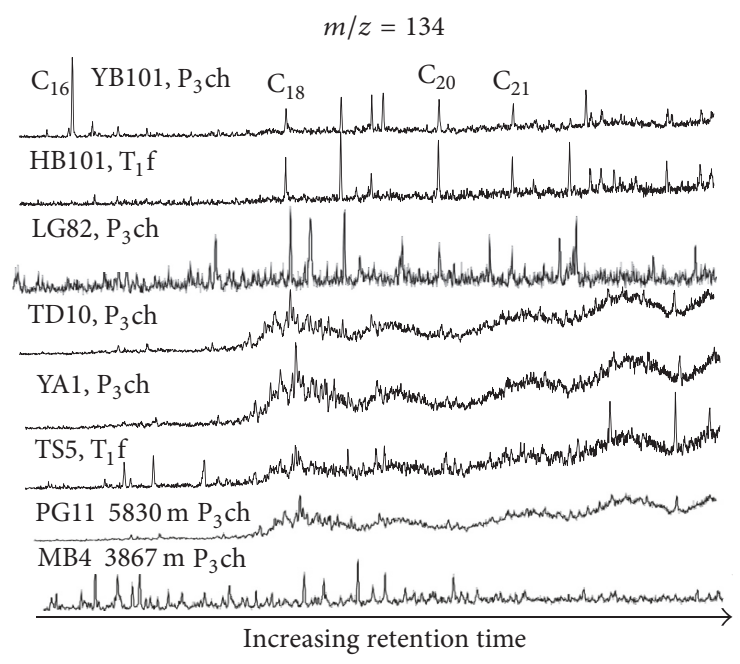

FIGURE 5: GC-MS selected ion mass chromatograms $(\mathrm{m} / z$ 134) for extractable organic matter from solid bitumen from western gas fields (wells YB101, HB101, and LG82) and eastern gas fields (wells TD10, YA1, TS5, PG11, and MB4). Abundant aryl isoprenoids are found to occur in wells in the west not in the east.

The occurrence of aryl isoprenoids in the Lower Silurian Longmaxi Fm and Upper Permian Dalong Fm alone is not enough to indicate the presence of green sulfur bacteria in the photic zone anoxic water column during the deposition [44]. However, elevated gammacerane/ $\mathrm{C}_{30} 17 \alpha, 21 \beta$-hopane ratios (Table 2), which have been used to infer marine stratification during source rock deposition [46], and $\delta^{34} S$ values as light as $-34.5 \%$ in the Upper Permian Dalong Fm pyrite are consistent with the distribution of aryl isoprenoids, indicating that green and purple sulfur bacteria may have been thriving in stratified euxinic environment. Green and purple sulfur bacteria are capable of recycling of $\mathrm{H}_{2} \mathrm{~S}$ generated by bacterial sulfate reduction, resulting in the generation of isotopically light intermediate valence sulfur species (e.g., elemental sulfur) or even of oxidized sulfate. This elemental sulfur or sulfate in turn may be reduced to even lighter $\mathrm{H}_{2} \mathrm{~S}$ by subsequent bacterial sulfate reduction [47]. Subsequently, the isotopically light $\mathrm{H}_{2} \mathrm{~S}$ was precipitated mainly as pyrite with very light $\delta^{34} \mathrm{~S}_{\mathrm{py}}$ values of $-32.6 \%$ and $-34.5 \%$ in Dalong Fm shales GZ17 and GZ18, respectively. The differences in $\delta^{34} S$ values between sulfate and pyrite are up to $48.5 \%$ as found in the GZ18 shale (assuming that late Permian seawater has a $\delta^{34} S$ of $14 \%$; [48]). Small amounts of isotopically light $\mathrm{H}_{2} \mathrm{~S}$ may have been incorporated into labile organic matter in water columns and sediment/water boundary with formation time overlapping with pyrite precipitation [49]. Most of the organic sulfur may have been formed during early diagenesis in sediments, a relatively closed system to sulfate supply, and thus possess significantly heavier $\delta^{34} \mathrm{~S}$ values than the associated pyrite ([14] and references therein). Kerogen samples have $\delta^{34} S$ values from $-30.6 \%$ to $15.9 \%$ o and, except a Cambrian sample ZB19, are from $4 \%$ to $27 \%$ heavier than the coexisting pyrite (Table 1). Alternatively, the ${ }^{34} \mathrm{~S}$ enrichment may have resulted from equilibrium isotope fractionation during the incorporation of polysulfides [50] or 


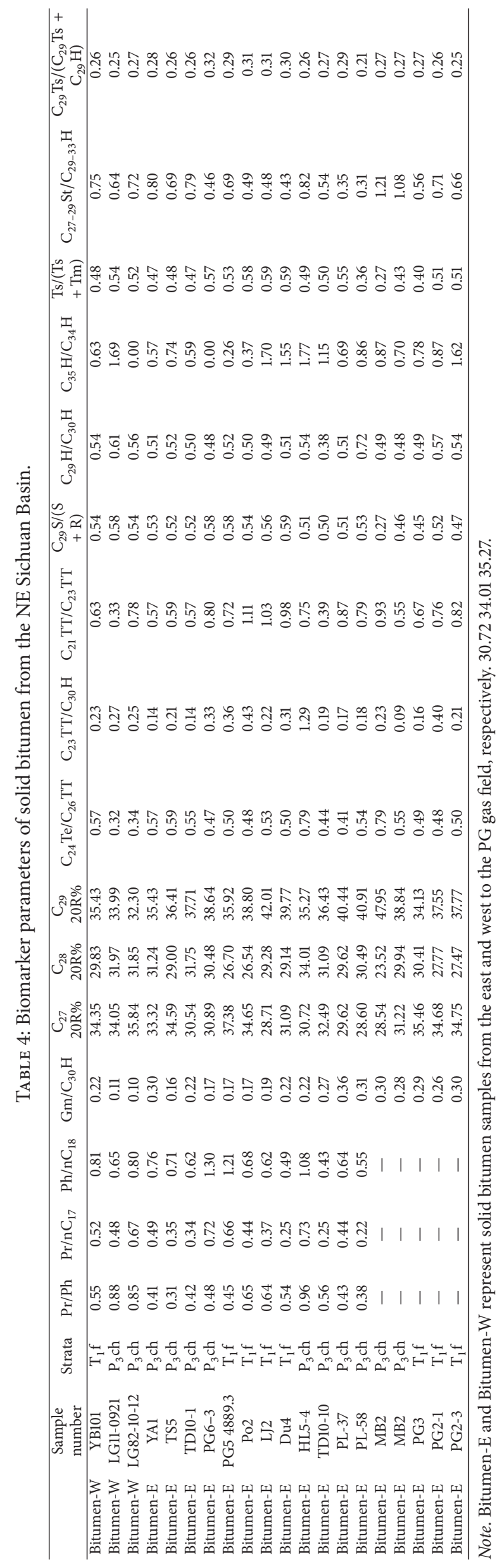




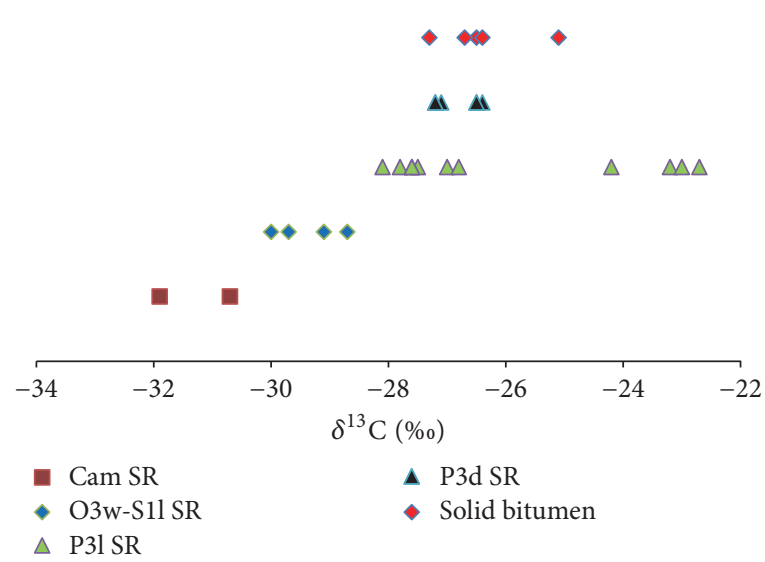

(a)

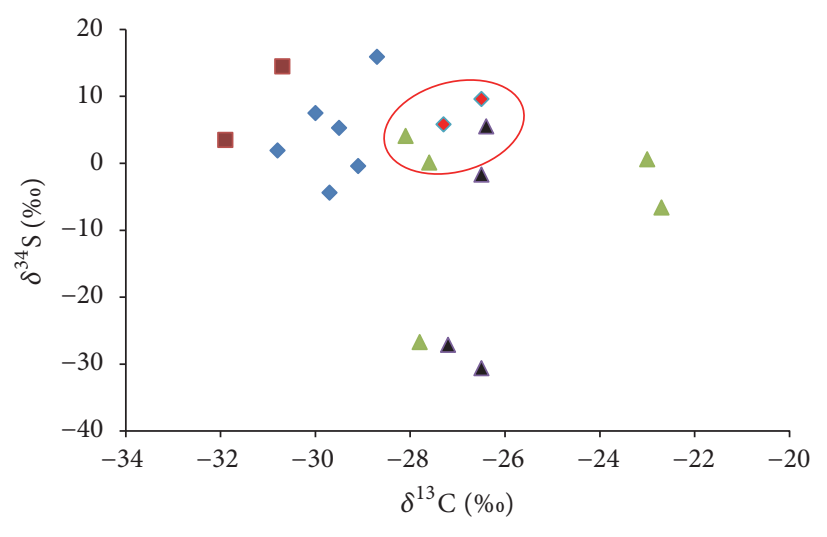

(b)

FIGURE 6: (a) Comparison of $\delta^{13} \mathrm{C}$ values and (b) cross-plot of $\delta^{13} \mathrm{C}$ and $\delta^{34} \mathrm{~S}$ values, from non-TSR altered solid bitumen and different source rocks. Note: SR is source rock in short.

TABLE 5: Solid bitumen $\delta^{13} \mathrm{C}$ and $\delta^{34} \mathrm{~S}$ values.

\begin{tabular}{lccccc}
\hline Location/well & $\begin{array}{c}\text { Sample } \\
\text { number }\end{array}$ & Age & $\begin{array}{c}\text { Depth } \\
(\mathrm{m})\end{array}$ & $\begin{array}{c}\delta^{13} \mathrm{C} \\
(\% \mathrm{o})\end{array}$ & $\begin{array}{c}\delta^{34} \mathrm{~S} \\
(\% \mathrm{o})\end{array}$ \\
\hline TD10 & TD10 & $\mathrm{P}_{3} \mathrm{ch}$ & - & $-26.5^{\#}$ & $9.6^{\#}$ \\
YB101 & YB101 & $\mathrm{T}_{1} \mathrm{f}$ & 6790 & $-273^{\#}$ & $5.8^{\#}$ \\
LG82 & LG82-13 & $\mathrm{P}_{3} \mathrm{ch}$ & - & -26.7 & - \\
LG11 & LG11-921 & $\mathrm{P}_{3} \mathrm{ch}$ & - & -26.4 & - \\
HB101 & HB101 & T1f & & -25.1 & \\
\hline
\end{tabular}

Note. See Table 1 note; ${ }^{\#}$ from Cai et al. (in press).

bacteriogenic sulfide [51], in which aqueous $\mathrm{S}_{x}{ }^{2-}$ species have been shown to be ${ }^{34} \mathrm{~S}$ enriched by a value between about $3 \%$ and $6 \%$ at equilibrium compared with coexisting $\mathrm{HS}^{-}$.

The pyrite and organic sulfur from euxinic environment as recorded in samples GZ17 and GZ18 show lighter sulfur isotopes than from noneuxinic environment from overlying Longtan Fm (samples 10-VI-40 and 10-VI-56) at the Huayinshan area. This result is consistent with Engel and Zumberge (2007) who showed that oils derived from kerogens deposited from euxinic environment have significantly lighter $\delta^{34} \mathrm{~S}$ values than those derived from noneuxinic source rocks.

Aryl isoprenoids were detected from the Lower Silurian shale samples HYS-6, HYS-8, HYS-11, and TJ-7-104, but not samples Guanba, Shiniulan, and ZB21. These samples show similar maturity; thus, it is less likely for the OM maturity to control the occurrence of aryl isoprenoids. Instead, the distribution may result from euxinic environment or aromatisation of carotenoid $\beta$-carotene [44]. It is hard to determine which one is the origin for the Lower Silurian aryl isoprenoids without analyses of carbon or sulfur isotopic composition. The Lower Silurian shales do not show significantly lighter kerogen $\delta^{34} S$ values than shales without the distribution of aryl isoprenoids in the Lower Silurian (Table 1). These features are different from the $\mathrm{P}_{3} \mathrm{~d}$ euxinic source rocks with very light sulfur isotopic composition. However, isotopically heavy organic sulfur was reported from euxinic basins across the Frasnian-Famennian boundary in the Kowala-Holy Cross Mountains, Poland [52] and during the Early Cambrian in the Tarim Basin [15], where organic sulfur is proposed to have been formed in sediments without significant amounts of $\mathrm{H}_{2} \mathrm{~S}$ contributed from the overlying water columns. Therefore, the euxinic environment for the Lower Silurian shales cannot be ruled out. The shales are characterized by uncommon bioturbation, occasional planar lamination, and abundant graptolites but low diversity of fossils [31], suggesting that it was deposited in a restricted and anoxic even euxinic environment [53].

5.2. Correlation of Solid Bitumen with Kerogen Based on $\delta^{13} C$ Values and Biomarkers. In the study area, rapid sedimentation and burial occurred during the Late Permian to the Middle Cretaceous when the peak oils were expected to generate from the Cambrian, Silurian, and Upper Permian and the oils in reservoirs were cracked to gas and solid bitumen; thus, the generation and cracking of the oils are expected to occur in semiclosed or closed systems where the thermal processes may have no significant carbon and sulfur isotope fractionation; that is, kerogen and its final cracking product, solid bitumen, may have similar $\delta^{13} \mathrm{C}$ and $\delta^{34} S$ values [12].

Solid bitumen which was not altered by TSR as indicated by the associated $\mathrm{H}_{2} \mathrm{~S}<0.5 \%$ has $\delta^{13} \mathrm{C}$ values of $-26.5 \%$ and $-27.3 \%$ (Table 5). These values are within the range from $-26.8 \%$ o to $-27.8 \%$ o for the $\mathrm{P}_{3} 1$ kerogen samples in the Bazhong-Dazhou depression, but different from those for $\mathrm{P}_{3} 1$ samples from well 10-VI at Huayinshan area, and $\mathrm{P}_{3} \mathrm{~d}$ source rock (Table 1, Figure 6). Unfortunately, no source rocks from the Bazhong-Dazhou depression have been analyzed for molecular composition to distinguish the two suites of $\mathrm{P}_{3} 1$ source rocks with different $\delta^{13} \mathrm{C}$ values in this study. However, sample $10-\mathrm{VI}-16$ source rock has a $\delta^{13} \mathrm{C}$ value of $-28.1 \%$ o close to source rocks in the Bazhong-Dazhou depression 
and shows that $\mathrm{C}_{27}-\mathrm{C}_{29}$ steranes were dominated by $\mathrm{C}_{27}$ sterane and $\mathrm{C}_{27}-\mathrm{C}_{29}$ sterane/ $\mathrm{C}_{29}-\mathrm{C}_{33}$ hopane ratio (of 0.85 ) higher than other samples $(<0.65)$ from well 10-VI with heavier $\delta^{13} \mathrm{C}$ values (Table 3 ). These characteristics indicate that organic matter in the sample $10-\mathrm{VI}-16$ is contributed more from marine planktonic algae including dinoflagellates, chrysophytes, and diatoms (Volkman, 1986) [41] and less from terrigenous plant inputs.

In contrast, $\mathrm{P}_{3} 1$ source rock samples from well 10-VI in the Huayingshan area (except sample 10-VI-16) have $\mathrm{C}_{27}-\mathrm{C}_{29}$ steranes dominated by $\mathrm{C}_{29}$ sterane, a lower sterane/hopane ratio $(<0.70)$, and $\delta^{13} \mathrm{C}$ values $2 \%$ to $5 \%$ heavier than those in the Bazhong-Dazhou depression. Here, terrigenous plant input may have been significant. The Cambrian and Silurian source rock samples have $\delta^{13} \mathrm{C}$ values from $-1.3 \%$ o to $-5.5 \%$ lighter than the non-TSR-altered solid bitumen. The significant differences between the source rock and the solid bitumen suggest that these samples are less likely to have been parent source rocks for the solid bitumen, assuming that the kerogen and subsequent oil cracking occurred in relatively closed system and no significant fractionation occurred during the cracking.

In summary, the non-TSR altered solid bitumen may have been derived from the $\mathrm{P}_{3} 1 / \mathrm{P}_{3} \mathrm{~W}$ oil-prone kerogen or sapropelic-dominated source rocks in the Bazhong-Dazhou depression based on $\delta^{13} \mathrm{C}$ values and biomarkers, supporting the conclusions made by Borjigen et al. [4] and Jin et al. [3].

5.3. Correlation of Solid Bitumen with Kerogen Based on Aryl Isoprenoid Distribution and $\delta^{34} S$ Values. Aryl isoprenoids, molecular indicators of photic zone euxinia or aromatisation of carotenoid $\beta$-carotene, were detected in several Dalong Fm $\left(\mathrm{P}_{3} \mathrm{~d}\right)$ and Lower Silurian source rocks. The $\mathrm{P}_{3} \mathrm{~d}$ source rocks with aryl isoprenoids have $\delta^{34} S_{\text {kero }}$ as low as $-31 \%$, while the Lower Silurian source rocks show variable $\delta^{34} \mathrm{~S}_{\text {kero }}$ values. No aryl isoprenoids were detected from the analyzed solid bitumen in the eastern gas fields suggesting that the precursor oils of the eastern solid bitumen are unlikely derived from the Dalong Fm $\left(\mathrm{P}_{3} \mathrm{~d}\right)$ or the Lower Silurian source rocks. In contrast, part of the $\mathrm{P}_{3} 1 / \mathrm{P}_{3} \mathrm{w}$ source rocks have $\delta^{34} \mathrm{~S}_{\text {kero }}$ values from $0.1 \%$ o to $4.1 \%$, which are close to those of the solid bitumen with values as low as $5.8 \%$ (Table 2 ). These source rocks show no detectable aryl isoprenoids. Thus, the source rocks can be correlated with the solid bitumen in the eastern gas fields. In contrast, aryl isoprenoids have been detected from the solid bitumen in wells HB101, YB101, and LG82 in the western gas field (Figure 5). The precursor oil for this solid bitumen may have source rocks different from those in the east, or at least may have precracking oils mixed with oils derived from other source rocks containing aryl isoprenoids. Because the western solid bitumen shows $\delta^{13} \mathrm{C}$ values from -27.3 to $-25.1 \%$ and $\delta^{34} \mathrm{~S}$ value of $5.8 \%$ (Table 5 ), which are significantly different from the P3d source rock but within the range of the $S_{1} 1$ kerogen isotopic composition $(-28.7$ to $-30.8 \%$ or for $\delta^{13} \mathrm{C}$ and -4.4 to $15.9 \%$ or for $\delta^{34} \mathrm{~S}$, Table 1$)$, thus, a significant contribution from the $\mathrm{S}_{1} 1$ but not $\mathrm{P}_{3} \mathrm{~d}$ source rock can be concluded although limited data are available. This proposal is supported by the low maturity for the $\mathrm{P}_{3} \mathrm{~d}$ source rock in the west with $R_{o}$ of $0.8 \%$. The low maturity indicates that it is unlikely for the oil derived from the $\mathrm{P}_{3} \mathrm{~d}$ source rock to have been cracked to gas and solid bitumen as found in the western gas fields.

\section{Conclusions}

Potential source rocks for Upper Permian and Lower Triassic solid bitumen in NE Sichuan Basin show significant differences in maturity, $\mathrm{C}$ and $\mathrm{S}$ isotopic compositions, and depositional environment with Lower Silurian $\left(\mathrm{S}_{1} \mathrm{l}\right)$ and Upper Permian Dalong Formation $\left(\mathrm{P}_{3} \mathrm{~d}\right)$ source rocks containing aryl isoprenoids. Oils from the $\mathrm{S}_{1} \mathrm{l}$ (and less likely from $\mathrm{P}_{3} \mathrm{~d}$ due to lower maturity) source rocks may have migrated to the western gas fields but not to the east, which was followed by second phase of emplacement of oils from the Upper Permian Longtan Formation $\left(\mathrm{P}_{3} \mathrm{l}\right)$ to both western and eastern gas fields. Subsequently, the oils were cracked to solid bitumen and natural gases, resulting in significant differences in the chemical and carbon isotopic compositions in the western and eastern natural gases (Cai et al., 2011) $[19,20]$ and aryl isoprenoids occurrence only in the western solid bitumen but not in the east. This case-study tentatively shows that $\delta^{13} \mathrm{C}$ and $\delta^{34} \mathrm{~S}$ values along with biomarkers have the potential to be used for the purpose of solid bitumen and source rock correlation in a rapidly buried basin. More work should be done to confirm it.

\section{Conflicts of Interest}

The authors declare that they have no conflicts of interest.

\section{Acknowledgments}

This work is financially supported by China National Funds for Distinguished Young Scientists (Grant no. 41125009) and NSFC Grant no. 41672143.

\section{References}

[1] J. Li, Z. Xie, J. Dai, S. Zhang, G. Zhu, and Z. Liu, "Geochemistry and origin of sour gas accumulations in the northeastern Sichuan Basin, SW China," Organic Geochemistry, vol. 36, no. 12, pp. 1703-1716, 2005.

[2] Y. Zhu, J. Wang, F. Hao, H. Zou, and X. Cai, "Geochemical characteristics and origin of natural gases from Xuanhan area, eastern Sichuan," Scientia Geologica Sinica, vol. 43, no. 3, pp. 518-532, 2008 (Chinese).

[3] X. Jin, C. Pan, S. Yu et al., "Organic geochemistry of marine source rocks and pyrobitumen-containing reservoir rocks of the Sichuan Basin and neighbouring areas, SW China," Marine and Petroleum Geology, vol. 56, pp. 147-165, 2014.

[4] T. Borjigen, J. Qin, X. Fu, Y. Yang, and L. Lu, "Marine hydrocarbon source rocks of the Upper Permian Longtan Formation and their contribution to gas accumulation in the northeastern Sichuan Basin, southwest China," Marine and Petroleum Geology, vol. 57, pp. 160-172, 2014.

[5] C. Cai, R. H. Worden, S. H. Bottrell, L. Wang, and C. Yang, "Thermochemical sulphate reduction and the generation of 
hydrogen sulphide and thiols (mercaptans) in Triassic carbonate reservoirs from the Sichuan Basin, China," Chemical Geology, vol. 202, no. 1-2, pp. 39-57, 2003.

[6] C. Cai, Z. Xie, R. H. Worden, G. Hu, L. Wang, and H. He, "Methane-dominated thermochemical sulphate reduction in the Triassic Feixianguan Formation East Sichuan Basin, China: Towards prediction of fatal $\mathrm{H}_{2} \mathrm{~S}$ concentrations," Marine and Petroleum Geology, vol. 21, no. 10, pp. 1265-1279, 2004.

[7] G. Zhu, S. Zhang, Y. Liang, J. Dai, and J. Li, "Isotopic evidence of TSR origin for natural gas bearing high $\mathrm{H}_{2} \mathrm{~S}$ contents within the Feixianguan Formation of the northeastern Sichuan Basin, southwestern China," Science in China, Series D: Earth Sciences, vol. 48, no. 11, pp. 1960-1971, 2005.

[8] C. Cai, K. Li, Y. Zhu et al., "TSR origin of sulfur in Permian and Triassic reservoir bitumen, East Sichuan Basin, China," Organic Geochemistry, vol. 41, no. 9, pp. 871-878, 2010.

[9] R. Sassen, "Geochemical and carbon isotopic studies of crude oil destruction, bitumen precipitation, and sulfate reduction in the deep Smackover Formation," Organic Geochemistry, vol. 12, no. 4, pp. 351-361, 1988.

[10] T. G. Powell and R. W. Macqueen, "Precipitation of sulfide ores and organic matter: Sulfate reactions at Pine Point, Canada," Science, vol. 224, no. 4644, pp. 63-66, 1984.

[11] C. Cai, A. Amrani, R. H. Worden et al., "Sulfur isotopic compositions of individual organosulfur compounds and their genetic links in the Lower Paleozoic petroleum pools of the Tarim Basin, NW China," Geochimica et Cosmochimica Acta, vol. 182, pp. 88-108, 2016.

[12] C. Cai, L. Xiang, Y. Yuan et al., "Sulfur and carbon isotopic compositions of the Permian to Triassic TSR and non-TSR altered solid bitumen and its parent source rock in NE Sichuan Basin," Organic Geochemistry, vol. 105, pp. 1-12, 2017.

[13] C. Cai, C. Zhang, R. H. Worden et al., "Application of sulfur and carbon isotopes to oil-source rock correlation: A case study from the Tazhong area, Tarim Basin, China," Organic Geochemistry, vol. 83-84, pp. 140-152, 2015.

[14] C. Cai, L. Xiang, Y. Yuan et al., "Marine C, S and N biogeochemical processes in the redox-stratified early Cambrian Yangtze ocean," Journal of the Geological Society, vol. 172, pp. 390-406, 2015.

[15] C. Cai, K. Li, M. Anlai et al., "Distinguishing Cambrian from Upper Ordovician source rocks: Evidence from sulfur isotopes and biomarkers in the Tarim Basin," Organic Geochemistry, vol. 40, no. 7, pp. 755-768, 2009.

[16] C. Cai, C. Zhang, L. Cai et al., "Origins of Palaeozoic oils in the Tarim Basin: Evidence from sulfur isotopes and biomarkers," Chemical Geology, vol. 268, no. 3-4, pp. 197-210, 2009.

[17] X. D. Fu, J. Z. Qin, Borjigen, and F. X. Wang, "Evaluation on Dalong Formation source rock in the North Sichuan Basin," Petroleum Geology \& Experiment, vol. 32, pp. 566-577, 2010.

[18] C. Cai, C. Zhang, H. He, and Y. Tang, "Carbon isotope fractionation during methane-dominated TSR in East Sichuan Basin gasfields, China: A review," Marine and Petroleum Geology, vol. 48, pp. 100-110, 2013.

[19] G. Y. Hu, C. Yu, D. Y. Gong, X. W. Tian, and W. Wu, “The origin of natural gas and influence on hydrogen isotope of methane by TSR in the Upper Permian Changxing and the Lower Triassic Feixianguan Formations in northern Sichuan Basin, SW China," Energy Exploration and Exploitation, vol. 32, no. 1, pp. 139-158, 2014.

[20] J. X. Dai, Coal-Generating Giant Gasfields and Their Source Rocks in China, Science Publishing House, 2014 (Chinese).
[21] M. Schoell, "Genetic characterization of natural gases," American Association of Petroleum Geologists Bulletin, vol. 67, no. 12, pp. 2225-2238, 1983.

[22] F. Lorant, A. Prinzhofer, F. Behar, and A.-Y. Huc, "Carbon isotopic and molecular constraints on the formation and the expulsion of thermogenic hydrocarbon gases," Chemical Geology, vol. 147, no. 3-4, pp. 249-264, 1998.

[23] Y. Ma, X. Guo, T. Guo, R. Huang, X. Cai, and G. Li, “The Puguang gas field: new giant discovery in the mature Sichuan Basin, southwest China," American Association of Petroleum Geologists Bulletin, vol. 91, no. 5, pp. 627-643, 2007.

[24] D. G. Liang, T. Guo, J. Chen, L. Bian, and Z. Zhao, "Some progresses on studies of hydrocarbon generation and accumulation in marine sedimentary regions, southern China (part 1): distribution of four suites of regional marine source rocks," Marine Origin Petroleum Geology, vol. 13, pp. 1-16, 2008 (Chinese).

[25] D. G. Liang, T. Guo, J. Chen, L. Bian, and Z. Zhao, "Some progresses on studies of hydrocarbon generation and accumulation in marine sedimentary regions, southern China (Part 2): geochemical characteristics of four suites of regional marine source rocks, South China," Marine Origin Petroleum Geology, vol. 14, pp. 1-15, 2009 (Chinese).

[26] D. G. Liang, T. L. Guo, L. Z. Bian, J. P. Chen, and Z. Zhao, "Some progresses on studies of hydrocarbon generation and accumulation in marine sedimentary regions, southern China (part 3): controlling factors on the sedimentary facies and development of palaeozoic marine source rocks," Marine Origin Petroleum Geology, vol. 14, pp. 1-19, 2009.

[27] J. Z. Qin, X. D. Fu, and B. Borjigen, "Evaluation of the excellent Triassic to Silurian marine hydrocarbon source rocks in Xuanhan-Daxian area of northeast Sichuan basin," Petroleum Geology \& Experiment, vol. 30, pp. 367-381, 2008 (Chinese).

[28] Y. Ma, S. Zhang, T. Guo, G. Zhu, X. Cai, and M. Li, "Petroleum geology of the Puguang sour gas field in the Sichuan Basin, SW China," Marine and Petroleum Geology, vol. 25, no. 4-5, pp. 357370, 2008.

[29] Y. M. Zhu, S. X. Gu, Y. Li, F. Hao, H. Y. Zou, and T. L. Guo, "Biological organic source and depositional environment of over-mature source rocks of Longtan Formation in the Sichuan Basin," Geochimica, vol. 41, pp. 35-44, 2012 (Chinese).

[30] B. Chen and D. C. Pi, "Silurian Longmaxi shale gas potential analysis in middle \& upper Yangtze region," China Petroleum Exploration, vol. 5, pp. 15-19, 2009 (Chinese).

[31] C. Zhang, Z. X. M, Y. H. Guo, and W. S. Zhang, "Geochemical characteristics and paleoenvironment reconstruction of the Longmaxi Formation in Southeast Sichuan and Northern Guizhou," Geological Science and Technology Information, vol. 32, pp. 124-130, 2013.

[32] B. Chen and Z. K. Lan, "Lower Cambrian shale gas resource potential in Upper Yangtze region," China Petroleum Exploration, vol. 5, pp. 10-14, 2009 (Chinese).

[33] R. E. Summons and T. G. Powell, "Identification of aryl isoprenoids in source rocks and crude oils: Biological markers for the green sulphur bacteria," Geochimica et Cosmochimica Acta, vol. 51, no. 3, pp. 557-566, 1987.

[34] T. C. Brown and F. Kenig, "Water column structure during deposition of Middle Devonian-Lower Mississippian black and green/gray shales of the Illinois and Michigan Basins: A biomarker approach," Palaeogeography, Palaeoclimatology, Palaeoecology, vol. 215, no. 1-2, pp. 59-85, 2004.

[35] J. J. Brocks, G. D. Love, R. E. Summons, A. H. Knoll, G. A. Logan, and S. A. Bowden, "Biomarker evidence for green and purple 
sulphur bacteria in a stratified Palaeoproterozoic sea," Nature, vol. 437, no. 7060, pp. 866-870, 2005.

[36] G. R. Sousa Júnior, A. L. S. Santos, S. G. De Lima et al., "Evidence for euphotic zone anoxia during the deposition of Aptian source rocks based on aryl isoprenoids in petroleum, Sergipe-Alagoas Basin, northeastern Brazil," Organic Geochemistry, vol. 63, pp. 94-104, 2013.

[37] S. A. Bailey and J. W. Smith, "Improved method for the preparation of sulfur dioxide from barium sulfate for isotope ratio studies," Analytical Chemistry, vol. 44, no. 8, pp. 1542-1543, 1972.

[38] J. Espitalié, G. Deroo, and F. Marquis, "Rock-Eval pyrolysis and its application 2," Revue de l'Institut Francais du Petrole, vol. 40, pp. 563-579, 1985.

[39] S. C. Zhang, A. D. Hanson, J. M. Moldowan et al., "Paleozoic oil-source rock correlations in the Tarim basin, NW China," Organic Geochemistry, vol. 31, no. 4, pp. 273-286, 2000.

[40] J. M. Moldowan, K. E. Peters, R. M. K. Carlson, M. Schoell, and M. A. Abu-Ali, "Diverse applications of petroleum biomarker maturity parameters," Arabian Journal for Science and Engineering, vol. 19, pp. 273-298, 1994.

[41] K. E. Peters, C. C. Walters, and J. M. Moldowan, The Biomarker Guide: 2. Biomarkers and Isotopes in Petroleum Exploration and Earth History, Cambridge University Press, Cambridge, UK, 2005.

[42] Y. Sun, S. Xu, H. Lu, and P. Cuai, "Source facies of the Paleozoic petroleum systems in the Tabei uplift, Tarim Basin, NW China: Implications from aryl isoprenoids in crude oils," Organic Geochemistry, vol. 34, no. 4, pp. 629-634, 2003.

[43] C. Zhang, Y. Zhang, and C. Cai, "Aromatic isoprenoids from the 25-65 Ma saline lacustrine formations in the western Qaidam Basin, NW China," Organic Geochemistry, vol. 42, no. 7, pp. 851855, 2011.

[44] M. P. Koopmans, S. Schouten, M. E. L. Kohnen, and J. S. Sinninghe Damsté, "Restricted utility of aryl isoprenoids as indicators for photic zone anoxia," Geochimica et Cosmochimica Acta, vol. 60, no. 23, pp. 4873-4876, 1996.

[45] S. Zhang, H. Huang, J. Su, M. Liu, and H. Zhang, "Geochemistry of alkylbenzenes in the Paleozoic oils from the Tarim Basin, NW China," Organic Geochemistry, vol. 77, pp. 126-139, 2014.

[46] J. S. Sinninghe Damsté, F. Kenig, M. P. Koopmans et al., "Evidence for gammacerane as an indicator of water column stratification," Geochimica et Cosmochimica Acta, vol. 59, no. 9, pp. 1895-1900, 1995.

[47] D. E. Canfield, R. Raiswell, J. T. Westrich, C. M. Reaves, and R. A. Berner, "The use of chromium reduction in the analysis of reduced inorganic sulfur in sediments and shales," Chemical Geology, vol. 54, no. 1-2, pp. 149-155, 1986.

[48] G. E. Claypool, W. T. Holser, I. R. Kaplan, H. Sakai, and I. Zak, "The age curves of sulfur and oxygen isotopes in marine sulfate and their mutual interpretation," Chemical Geology, vol. 28, pp. 199-260, 1980.

[49] S. H. Bottrell, R. J. G. Mortimer, I. M. Davies, S. Martyn Harvey, and M. D. Krom, "Sulphur cycling in organic-rich marine sediments from a Scottish fjord," Sedimentology, vol. 56, no. 4, pp. 1159-1173, 2009.

[50] A. Amrani and Z. Aizenshtat, "Mechanisms of sulfur introduction chemically controlled: $\delta^{34} \mathrm{~S}$ imprint," Organic Geochemistry, vol. 35, no. 11-12, pp. 1319-1336, 2004.

[51] A. Amrani, W. Said-Ahamed, M. D. Lewan, and Z. Aizenshtat, "Experiments on $\delta^{34} S$ mixing between organic and inorganic sulfur species during thermal maturation," Geochimica et Cosmochimica Acta, vol. 70, no. 20, pp. 5146-5161, 2006.

[52] M. M. Joachimski, C. Ostertag-Henning, R. D. Pancost et al., "Water column anoxia, enhanced productivity and concomitant changes in $\delta^{13} \mathrm{C}$ and $\delta^{34} \mathrm{~S}$ across the Frasnian-Famennian boundary (Kowala - Holy Cross Mountains/Poland)," Chemical Geology, vol. 175, no. 1-2, pp. 109-131, 2001.

[53] R. D. Pancost, K. H. Freeman, A. D. Herrmann, M. E. Patzkowsky, L. Ainsaar, and T. Martma, "Reconstructing Late Ordovician carbon cycle variations," Geochimica et Cosmochimica Acta, vol. 105, pp. 433-454, 2013. 

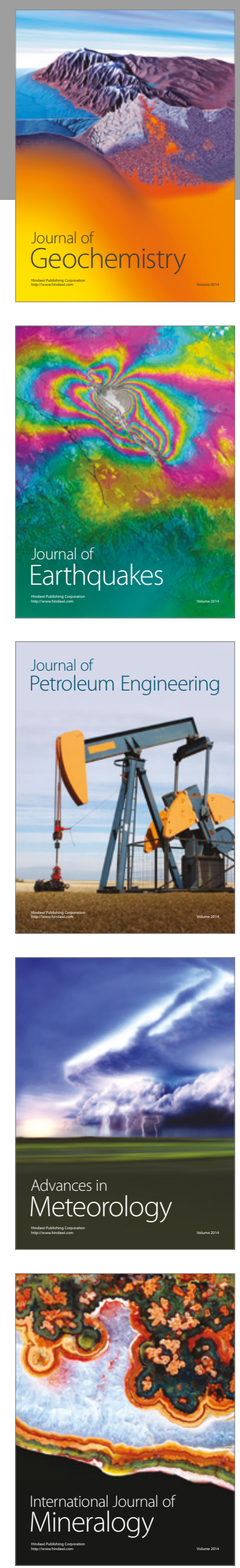
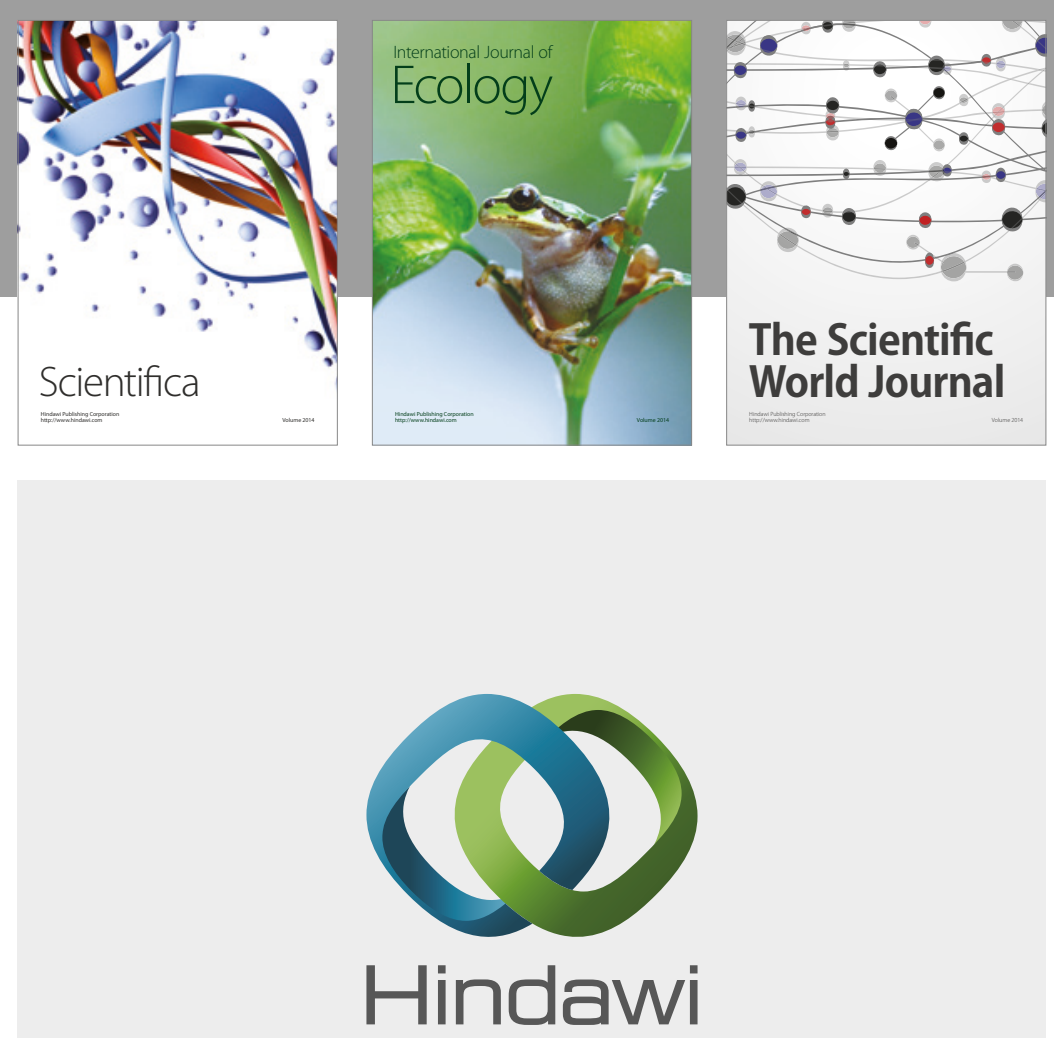

Submit your manuscripts at

https://www.hindawi.com
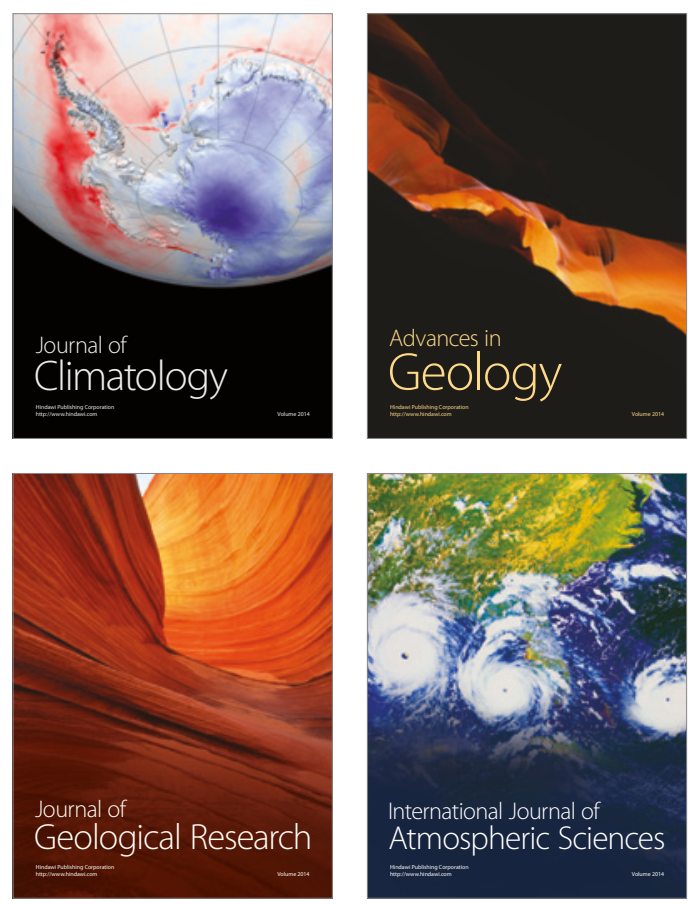

The Scientific

World Journal
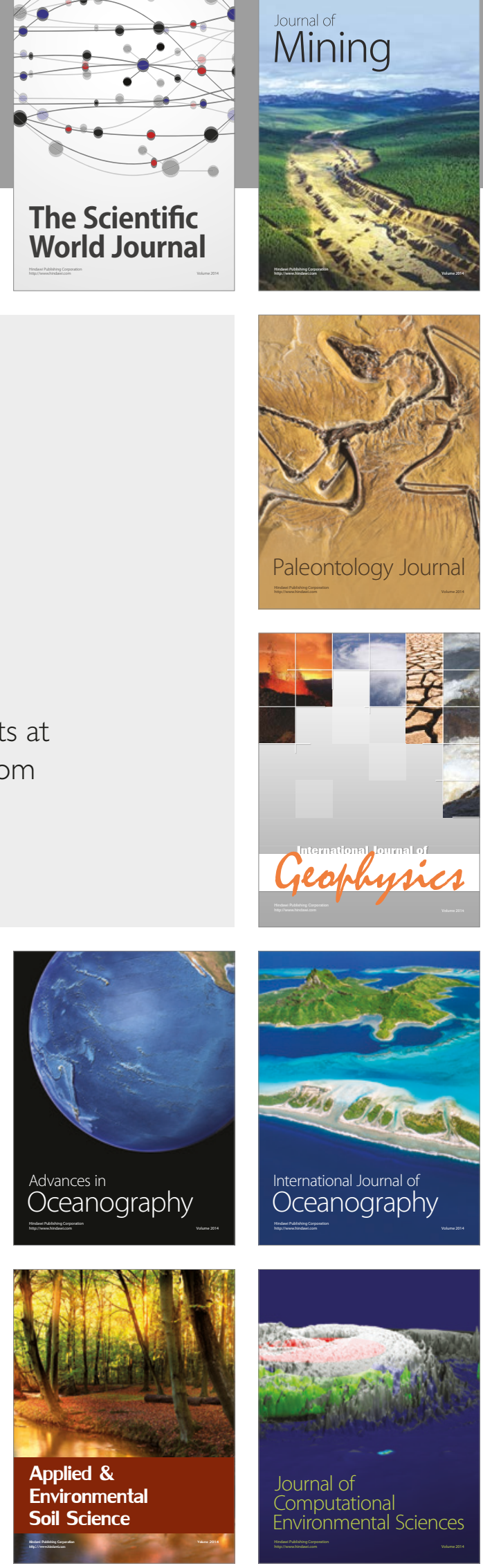